\title{
The Chlorination Behaviour and Environmental Fate of the Antiretroviral Drug Nevirapine in South African Surface Water
}

\author{
TP Wood ${ }^{\mathrm{a}, \mathrm{d}}$
}

\author{
A E Basson \\ C Duvenage ${ }^{c}$
}

E R Rohwer ${ }^{\mathrm{d}}$

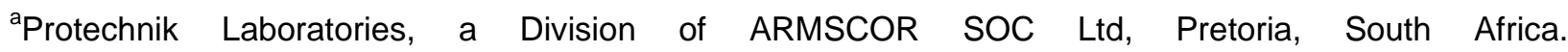
timw@protechnik.co.za

${ }^{\text {b}}$ Centre for HIV and STI: HIV Virology Section (Morris Laboratory), National Institute for Communicable Diseases (NICD), a division of the National Health Laboratory Service (NHLS), Johannesburg, South Africa

${ }^{\mathrm{C}}$ Department of Internal Medicine, 1 Military Hospital, South African Military Health Services, Pretoria, South Africa

${ }^{d}$ Department of Chemistry, University of Pretoria, Pretoria, South Africa.

\section{Abstract}

The wastewater treatment process, besides discharging pharmaceuticals into the environment, has been found to result in the formation of a variety of undescribed compounds. Here we investigate the laboratory scale chlorination of the commonly used anti-HIV drug Nevirapine, characterise its disinfection transformation products (DTPs), and using liquid chromatography with high resolution mass spectrometry, screen environmental surface water for these DTPs. Chlorination of Nevirapine was scaled up, fractioned by preparative chromatography and the 
fractions were tested in vitro for toxicity and anti-HIV activity. Nevirapine was found to be resistant to degradation at relevant chlorination levels, which may partially explain its ubiquitous presence in South African surface water. During simulated chlorination, a variety of DTPs with varying properties were formed, some of which were detected in the environment, close to wastewater treatment plants. Interestingly, some of these compounds, although not as toxic as Nevirapine, retained antiviral activity. Further purification and synthesis is required to fully characterise these novel molecules.

\section{Keywords}

Nevirapine, chlorination, wastewater, LC-MS, surface water, LC-QTOF

\section{Highlights}

- Nevirapine is resistant to chlorination; may explain its environmental prevalence

- Nevirapine forms a variety of chlorination disinfection transformation products in vitro

- These compounds were detected in the environment by UHPLC-QTOF

- The disinfection transformation products were non-toxic in vitro, with slight antiviral activity

- Potentially biologically active modified pharmaceuticals are released into the environment

\section{Introduction}

Over the past two decades researchers have shown that pharmaceuticals and personal care products (PPCP) are released into water courses as a result of human use (Ternes et al., 2001; Peng et al., 2014).The effect these compounds, at low concentrations, have on human health or aquatic fauna and flora have yet to be determined fully (Petrie et al., 2014; Roden et al., 2015). 
Furthermore, the development and promotion of drug resistance in bacterial populations has been postulated (Kümmerer, 2009).

Besides releasing pharmaceuticals into the environment, these compounds have also been found to be modified as a result of wastewater treatment. The resulting disinfection transformation products (DTPs), many of which are undescribed, are then released into the environment, which further complicates the impact of PPCPs on the environment. The mechanism and type of transformation product formation is dependent on the type of disinfection utilised. It has been found that pharmaceuticals may be modified by ozonation (Zimmermann et al., 2011), chloramination (Zhai et al., 2014) and chlorination (He et al., 2013; Bulloch et al., 2015). Chlorination is one of the more popular methods used to disinfect wastewater and has therefore received the most attention in the literature. In South Africa water disinfection is commonly achieved using chlorine gas. The Department of Water Affairs and Forestry (DWAF) requires that discharged wastewater should contain zero faecal coliforms per $100 \mathrm{~mL}$ with the caveat that residual chlorine may not be higher than $0.25 \mathrm{mg} / \mathrm{mL}$ (Leopold and Freese, 2009).

Chlorination, as a mechanism to treat wastewater and drinking water, has been the method of choice for a long time since it it is a cost effective and broad spectrum method of disinfection. In addition to this, chloramination of treated water ensures a longer duration of disinfection as chloramines have a longer half-life than free residual chlorine (Leopold and Freese, 2009).

Unfortunately chlorination has a number of drawbacks, such as the formation of disinfection byproducts during the disinfection process. A large number of toxic compounds may be formed through the interaction between chlorine and dissolved organic matter. Compounds such as the trihalomethanes and the haloacetic acids have been identified in previous decades and are now strictly regulated (Richardson et al., 2007). 
Very little is known about the chemical characteristics of pharmaceutical DTPs and their toxicity profiles cannot always be based on those of the parent compound. This was shown in the case of the chlorination of acetaminophen, which resulted in the production of the toxic compounds 1,4- benzoquinone and $\mathrm{N}$-acetyl-p-benzoquinone imine (Bedner and MacCrehan, 2006).

Besides adding complexity to the potential toxicity profile, the biological activities of many of the degradation products are not known. The degradation products of antivirals or antibiotics may retain antimicrobial properties or even gain additional activities. Inroads into understanding the transformation of antibiotics are being made by various researchers and it has been found that while most antibiotics lose their activity during water disinfection, a few do form biologically active transformation products(Dodd et al., 2009; Escher and Fenner, 2011; Mestankova et al., 2012; Keen and Linden, 2013). In addition to understanding the chemistry behind their transformation, various technologies are in development to effectively remove pharmaceuticals and their disinfection transformation products from wastewater (Prasse et al., 2015). These technologies are however in their infancy and have yet to be adopted widely in "first world countries", let alone in developing countries such as South Africa.

Recent research on the prevalence of HIV-1 antiretroviral compounds (ARVs) in South African surface water has shown that Nevirapine occurs ubiquitously in the environment (Wood et al., 2015). The drug is a non-nucleoside reverse transcriptase inhibitor (NNRTI) that is commonly used to prevent mother to child transmission of HIV and features as a first-line regimen for treatment of HIV-1 infection (Mofenson, 2010; Coovadia et al., 2012). Prasse and colleagues have shown that the compound also occurs in European surface water and its presence is attributable to inefficient removal during wastewater treatment (Prasse et al., 2010).

Vankova and co-workers showed that Nevirapine has low biodegradability in a closed bottle system (Vanková et al., 2010). Although this theoretical finding addresses the compound's 
ubiquitous presence in South African surface water (Wood et al., 2015), it does not describe how the compound reacts during wastewater treatment, if at all.

The antiretroviral class of compound has not been studied extensively in surface water across the world. This is most likely due to the regional prevalence of HIV. In addition to this, no research, to our knowledge, concerning the transformation behaviour of these drugs during the disinfection process has been described.

South Africa utilises more ARVs per capita than any other country in the world (WHO, 2013) which indicates that high amounts of these compounds would enter wastewater treatment works (WWTWs), that were not designed to remove pharmaceuticals. In addition to ineffective WWTWs, improper sanitation and illegal sewage release should also be considered. These factors, as well as the reduced expected dilution, in a water scarce region such as South Africa, lead one to expect that ARVs and their degradation products should be prevalent in the environment.

Here the reactivity of the antiretroviral drug Nevirapine to chlorine, in the form of sodium hypochlorite, is qualitatively studied. The degradation products that are formed as a result of chlorination are described and related to environmental water samples collected in South Africa. We proceed to show that although these disinfection transformation products of Nevirapine are not toxic, they may have the same or similar biological activity as the parent molecule. The environmental impact of releasing active, undescribed molecules from WWTWs has yet to be determined. 


\section{Materials and Methods}

\subsection{Chemical reagents}

Nevirapine was purchased from the United States Pharmacopeia, through Industrial Analytical (Johannesburg, South Africa) and stock solutions $(1 \mathrm{mg} / \mathrm{mL})$ were made up in methanol and stored at $-20^{\circ} \mathrm{C}$ until use. LC-MS grade water, methanol and dimethyl sulfoxide (DMSO) were purchased from Lab-Scan (Gliwice, Poland). Sodium hypochlorite from Merck (Johannesburg, South Africa), 10-14\%, was diluted in water to $0.4 \mathrm{M}$ and the concentration was found to be stable over time by iodometric titration. Monobasic and dibasic potassium phosphate (Merck) were used for buffering Nevirapine and $\mathrm{NaOCl}$ solutions to a final concentration of $10 \mathrm{mM}$. Ammonium Chloride, sodium thiosulphate and ascorbic acid were purchased from Radchem (Johannesburg, South Africa), formic acid from Sigma-Aldrich (Johannesburg, South Africa) and $20 \mathrm{~mL}$ borosilicate amber vials with PTFE caps from Macherey-Nagel (Düren, Germany). Pharmaceutical Nevirapine was obtained from Aspen (Johannesburg, South Africa) and utilized for large scale experimentation to reduce costs. Water and acetonitrile, each with $0.1 \%$ formic acid were obtained from Burdick \& Jackson (Muskegon, USA). All buffers and reagents were formulated using LC-MS grade water (non-South African origin).

\subsection{Chlorination reactions}

Nevirapine $(20 \mu \mathrm{g} / \mathrm{mL})$ diluted in either LC-MS grade water, $10 \mathrm{mM}$ phosphate buffer $\mathrm{pH} 5.8$ or $10 \mathrm{mM}$ phosphate buffer $\mathrm{pH} 8$ was combined in equal volumes with $\mathrm{NaOCl}$ diluted in either of the aforementioned solvents (to yield 50, 100, 200 or $500 \mu \mathrm{M} \mathrm{NaOCl}$ ) and stirred at room temperature $\left(20^{\circ} \mathrm{C}+-1^{\circ} \mathrm{C}\right)$. Aliquots were taken from the reaction at $1,5,10,20,30,60$ and 120 min and then again at 24 hours. Aliquots were analysed by HPLC-UV, UHPLC-QqQ and UHPLC-QTOF. 
To identify an effective quenching agent, sample fractions $(1 \mathrm{~mL})$ for each time course were added to either sodium thiosulphate, ascorbic acid or ammonium chloride to yield a twofold molar excess (compared to $\mathrm{NaOCl}$ concentration), analysed by LC-MS plug injection and compared to unquenched data. In order to generate the most accurate data for a particular time point, unquenched reactions were incubated in the LC autosampler. Plug injections were performed using an Agilent 1290 series UHPLC coupled to an Agilent 6460 triple quadrupole (Agilent). Mobile phases consisted of water $(\mathrm{A})$ and acetonitrile (B) both with $0.1 \%$ formic acid, held at $50 \% \mathrm{~B}$ at a flow rate of $0.4 \mathrm{~mL} / \mathrm{min}$. Sequential $15 \mu \mathrm{L}$ plug injections (no column) of a sample incubated on the LC-MS autosampler, held at $\left(20^{\circ} \mathrm{C}+-1^{\circ} \mathrm{C}\right)$, were analysed by mass spectrometry in MS2 scan mode by positive electrospray ionisation. Source conditions: gas temperature, $250^{\circ} \mathrm{C}$; gas flow, $8 \mathrm{~L} / \mathrm{min}$; nebulizer, $35 \mathrm{psi}$; sheath gas temperature, $300{ }^{\circ} \mathrm{C}$; sheath gas flow, $10 \mathrm{~L} / \mathrm{min}$; capillary voltage, $3000 \mathrm{~V}$ and nozzle voltage, $0 \mathrm{~V}$.

For kinetics studies Nevirapine $(4 \mu \mathrm{M})$ diluted in either LC-MS grade water, $10 \mathrm{mM}$ phosphate buffer $\mathrm{pH} 5.8,10 \mathrm{mM}$ phosphate buffer $\mathrm{pH} 8$ or WWTW effluent from the Zeekoegat plant was combined in equal volumes with $\mathrm{NaOCl}$ diluted in either of the aforementioned solvents (to yield $2 \mu \mathrm{M}$ Nevirapine and $20 \mu \mathrm{M} \mathrm{NaOCl})$ and stirred at room temperature $\left(20^{\circ} \mathrm{C}+-1^{\circ} \mathrm{C}\right)$. Aliquots were taken from the reaction at 10 second intervals and combined with $\mathrm{NH}_{4} \mathrm{Cl}$ to give a two-fold molar excess with respect to $\mathrm{NaOCl}$. Samples were analysed by UHPLC-QTOF immediately after the last time course was sampled. An external 6 point calibration of Nevirapine in the matching reaction solvent was utilised for quantitative purposes and analysed in MassHunter Quant (Agilent). 


\subsection{LC-UV analysis of Chlorination Reactions}

The LC-UV system consisted of an Agilent 1100 series binary pump LC coupled to an Agilent diode array detector (254 nm with $400 \mathrm{~nm}$ reference). A $1.8 \mu \mathrm{m}$ Zorbax Eclipse Plus C18, $2.1 \times 50 \mathrm{~mm}$, column was used to separate a $15 \mu \mathrm{L}$ injection of the reaction products at a flow rate of $0.2 \mathrm{~mL} / \mathrm{min}$ at room temperature. Mobile phase A consisted of water with $0.1 \%$ formic acid and mobile phase B was acetonitrile with $0.1 \%$ formic acid. The gradient was as follows: 0 min, 5\% B; 20 min, 95\%B; $22 \min 95 \%$ B; 30 min, 5\% B; 40 min, 5\%B.

\subsection{Large Scale Preparation of Nevirapine Chlorination Reaction Products}

$1.8 \mathrm{~g}$ of pharmaceutical Nevirapine (Aspen) tablets were crushed and resuspended in $25 \%$ $\mathrm{HCl}$. The solution was clarified by centrifugation (3000 rpm for $30 \mathrm{~min}$ ) and the supernatant containing approximately $1 \mathrm{~g}$ of Nevirapine was collected. The yield of this acid extraction was determined by UHPLC-QTOF analysis as compared to an external calibration curve.

Acid extracted Nevirapine was diluted in either $100 \mathrm{mM}$ phosphate buffer $(\mathrm{pH}$ 8) or $10 \mathrm{mM}$ Phosphate buffer ( $\mathrm{pH} 5.8$ ) to $1.5 \mathrm{mg} / \mathrm{mL}, 0.4 \mathrm{M} \mathrm{NaOCl}$ was added daily for a period of four days and the reactions were monitored by UHPLC-QTOF analysis. Upon reaching the maximum diversity of reaction products, the mixtures were dried by rotary evaporation (Buchi, Switzerland) at $40^{\circ} \mathrm{C}$ under vacuum. The total basic and acidic reactions were diluted in dimethyl sulphoxide to $1 \mathrm{mg} / \mathrm{mL}$ for toxicity studies.

The dried and crushed acidic reaction mixture was dissolved in water and fractioned by centrifugation into aqueous and non-aqueous fractions. These were dried, as before, and diluted in dimethyl sulphoxide to $1 \mathrm{mg} / \mathrm{mL}$ for toxicity studies. 
Both the acidic and basic reactions were separated using preparative chromatography. $100 \mathrm{mg}$ of each reaction in water $(100 \mathrm{mg} / \mathrm{mL})$ was loaded onto a Biotage SNAP Ultra C18 $(12 \mathrm{~g})$ column and separated on a gradient of acetonitrile and water (both with $0.1 \%$ formic acid) over $30 \mathrm{~min}$ at a flow rate of $10 \mathrm{~mL} / \mathrm{min}$. Fractions were collected and dried by vacuum centrifugation (Martin Christ RVC 2-33IR) at $2 \mathrm{mBar}, 40^{\circ} \mathrm{C}, 900 \mathrm{rpm}$ for 12 hours. Dried fractions were resuspended in DMSO $(1 \mathrm{mg} / \mathrm{mL})$ and subjected to toxicity and activity screening.

\subsection{Environmental Sample Collection and Extraction}

Grab samples were collected from all the major rivers and lakes (man-made) in South Africa as part of a multi-year water quality study. Samples were collected in "virgin" borosilicate Schott bottles and transported to the laboratory at room temperature. Sampling locations were chosen based on proximities to wastewater treatment works (WWTW) and human settlements. To provide a comprehensive picture of a specific body of water, multiple samples were taken from different locations in a sampling site. Samples were stored at $-20^{\circ} \mathrm{C}$ until extraction after which extracts were stored at $-20^{\circ} \mathrm{C}$ until analysis.

$500 \mathrm{~mL}$ of each environmental sample was filtered using a $1 \mu \mathrm{m}$ glass-fibre syringe driven filter (Pall) and extracted using the Smart Prep Extraction (Horizon, Salem, USA); an automated offline solid phase extraction instrument. Briefly 6 cc Oasis HLB, 500 mg (Waters) cartridges were conditioned with $4 \mathrm{~mL}$ methanol followed by $6 \mathrm{~mL}$ of HPLC Grade water. $500 \mathrm{~mL}$ of sample was then introduced at a flow rate of $10 \mathrm{~mL} / \mathrm{min}$ after which cartridges were dried under nitrogen for three minutes. Cartridges were then eluted twice with $5 \mathrm{~mL}$ of methanol and dried

under a gentle stream of nitrogen to $500 \mu \mathrm{L}$. All extractions were performed at $18^{\circ} \mathrm{C}\left(+-2^{\circ} \mathrm{C}\right)$. 


\subsection{UHPLC QTOF Analysis}

Environmental concentrations of Nevirapine were reported previously and national samples were analysed by UHPLC-QTOF in full scan, "auto MS" and "all ions" mode. Similarly, chlorination reactions of Nevirapine at varying concentrations of $\mathrm{NaOCl}$ and $\mathrm{pH}$ (after $1 \mathrm{~min}$ ) were analysed in order to characterise the resulting reaction products. In addition to these, the large scale chlorination reactions were monitored by UHPLC-QTOF.

$1 \mu \mathrm{L}$ of each sample was separated on an Agilent 1290 UHPLC using an HPH $2.1 \times 100 \mathrm{~mm}$ Poroshell column (Agilent) with water and acetonitrile (both with $0.1 \%$ formic acid) as mobile phases at a flow rate of $0.5 \mathrm{~mL} / \mathrm{min}$. The gradient was as follows: $3 \mathrm{~min}, 2 \% \mathrm{~B}$ (organic); $22 \mathrm{~min}$ 100\%; $25 \mathrm{~min}, 100 \%$; $27 \mathrm{~min}, 2 \%$ and $30 \mathrm{~min}, 2 \%$.

Eluting compounds were analysed by positive electrospray QTOF fitted with an iFunnel source. Source conditions: gas temperature, $200^{\circ} \mathrm{C}$; gas flow, $15 \mathrm{~L} / \mathrm{min}$; nebulizer, $40 \mathrm{psi}$; sheath gas temperature, $400{ }^{\circ} \mathrm{C}$; sheath gas flow, $12 \mathrm{~L} / \mathrm{min}$; capillary voltage, $3500 \mathrm{~V}$, nozzle voltage, $500 \mathrm{~V}$ and fragmentor, $365 \mathrm{eV}$.

Data obtained from full scan and auto-MS analysis of Nevirapine reactions were manually inspected using MassHunter Qual (Agilent) and exported to Mass Profiler (Agilent) for analysis. Features present in the control reactions (Nevirapine without $\mathrm{NaOCl}$ and $\mathrm{NaOCl}$ without Nevirapine) and blank injections were subtracted from the reaction data sets to determine unique reaction products. These features were inspected manually and exported to MassHunter PCDL Manager (Agilent) to create a database containing information on each reaction product's accurate mass, retention time and MS/MS behaviour. This database was then applied to environmental samples to determine the presence of reaction products in the environment. 
Molecular Structure Correlator (Agilent) was used to calculate precursor and fragment formulas and correlate actual MS/MS spectra with theoretical fragments of proposed structures. The structures were proposed (manually) for each of the major reaction products.

\subsection{In Vitro Toxicity and Antiviral Activity}

The CellTiter 96 AQueous One Solution Cell Proliferation Assay System (Promega, Madison, USA) was used to determine the toxicity (Barltrop et al., 1991) (Barltrop et al., 1991) of Nevirapine chlorination reaction product fractions in $293 \mathrm{~T}$ cells (Graham et al., 1977). This was compared to the toxicity of pharmaceutical grade as well as analytical grade Nevirapine. Sample toxicity, as reflected by cell viability, was measured by the bioreduction of a MTS tetrazolium compound (MTS) to a coloured formazan product in the culture medium. The formazan product was spectrophotometrically quantified with a VesraMax microplate reader (Molecular Devices, Sunnyvale, USA). The degree of sample toxicity was related to the MTS-to-formazan conversion by the cells.

Sample titration into complete Dulbecco's Modified Eagle Medium (DMEM) (Life Technologies, Johannesburg, South Africa) supplemented with fetal bovine serum (Hyclone, GE, Little Chalfont, UK), 1 M HEPES (Life Technologies, Johannesburg, South Africa) and $10 \mathrm{mg} / \mathrm{mL}$ Gentamicin (Sigma-Aldrich, Johannesburg, South Africa) provided a range of concentrations for toxicity testing. Unexposed cells were used as a negative control. Incubation commenced for 2 days at $37^{\circ} \mathrm{C}$ under $5 \% \mathrm{CO}_{2}$ in a humidified atmosphere. After the addition of the MTS reagent, plates were incubated for 1.5 hours after which spectrophometric absorbances were read at 490 $\mathrm{nm}$, with $690 \mathrm{~nm}$ as reference wavelength. A viability of $0 \%$ indicates total cells death while a viability of $100 \%$ indicates full cell viability. Cytotoxic concentration-50 $\left(\mathrm{CC}_{50}\right)$ values were calculated and indicate the sample concentration at which $50 \%$ of the cells are viable. 
Anti-HIV activity was determined over non-toxic sample concentrations. Dilutions of each of the reaction product fractions were titrated in 96-well culture plates as described above. After the addition of cells and virus, the plates were incubated for 48 hours at $37^{\circ} \mathrm{C}$ under $5 \% \mathrm{CO}_{2}$ in a humidified atmosphere. A standard HIV-1 subtype C isolate, MJ4, was used to screen for antiviral activity of the samples. A medium control (cells, virus and growth medium) was included. After incubation the Bright Glo ${ }^{\mathrm{TM}}$ Reagent (Promega) was used to assay for the expression of firefly luciferase in the plate wells (De Wet et al., 1987). Bioluminescence was quantified on a Victor-3 1420 Multi Label Counter (Perkin Elmer). The medium control was used as the uninhibited control. The percent viral activity was calculated as the factor of the bioluminescence of the test sample and that of the virus control.

A viral activity of $0 \%$ indicates complete viral inhibition while a viral activity of $100 \%$ indicates no inhibition (full viral activity). Inhibitory concentration-50 $\left(\mathrm{IC}_{50}\right)$ values were calculated and indicated the concentration of sample at which $50 \%$ of the viruses were inhibited. During the activity screening, a decrease in luciferase activity can be observed over toxic concentrations as a result of compromised cell viability, and not as a result of inhibition of the virus. An untreated cell control (media only) is used as a reference for $100 \%$ cell viability (no toxicity).

\section{Results and Discussion}

\subsection{Chlorination Reactions}

Various chromatographic systems were utilised throughout this research and although they differ by instrument type (UV detection, triple quadrupole and qTOF) a high level of correlation was found between the data. Three concentrations of Nevirapine were used in this research in order to represent environmental concentrations (low, $2 \mu \mathrm{M}$ ) as well as having concentrations 
high enough to detect (medium, $37 \mu \mathrm{M}$ ) transformation products and purify them (high, 5620 $\mu \mathrm{M})$.

The efficacy of ammonium chloride, sodium thiosulfate and citric acid as quenching agents was evaluated. Researchers (Bedner and MacCrehan, 2006; Soufan et al., 2012) have warned of the potential of sodium thiosulphate to reverse chlorination reactions, and this was found to be the case for Nevirapine. This was found by comparing quenched and unquenched LC-MS plug injection spectra in which the ion intensity of the Nevirapine pseudomolecular ion was compared. This highlights the fact that Nevirapine oxidation by $\mathrm{NaOCl}$ may be reversed (with the addition of a reducing agent such as sodium thiosulphate). Similarly, ascorbic acid was found to reverse Nevirapine chlorination reactions. Fortunately $\mathrm{NH}_{4} \mathrm{Cl}$ was found to halt the reaction while not inducing additional reactions, as shown by the un-quenched control. Autosampler reactions (unquenched) and quenched stirred reactions were found to be comparable when analysed by plug injection, which indicates that the reaction is not adversely influenced by an increase in volume. Thus, large scale $(10 \mathrm{~mL})$ stirred reactions were utilised throughout in order to analyse identical samples multiple times across a number of analytical platforms.

UV analysis of chlorination reactions ( $37 \mu \mathrm{M}$ Nevirapine to 50, 100, 200 and $500 \mu \mathrm{M} \mathrm{NaOCl}$ ) showed that the compound reacts almost immediately (the earliest time course was one minute) and then remains relatively constant over the time course up to 24 hours. In Figure 1 the 1 minute reaction of Nevirapine with $\mathrm{NaOCl}$ is overlaid with the 24 hour reaction (at $\mathrm{pH} 8)$. The peak area of Nevirapine remains constant, whereas the reaction products show variability over time. The dynamic range of Nevirapine detection was verified by injection of a calibration curve and was found to be linear across the concentration range tested. 


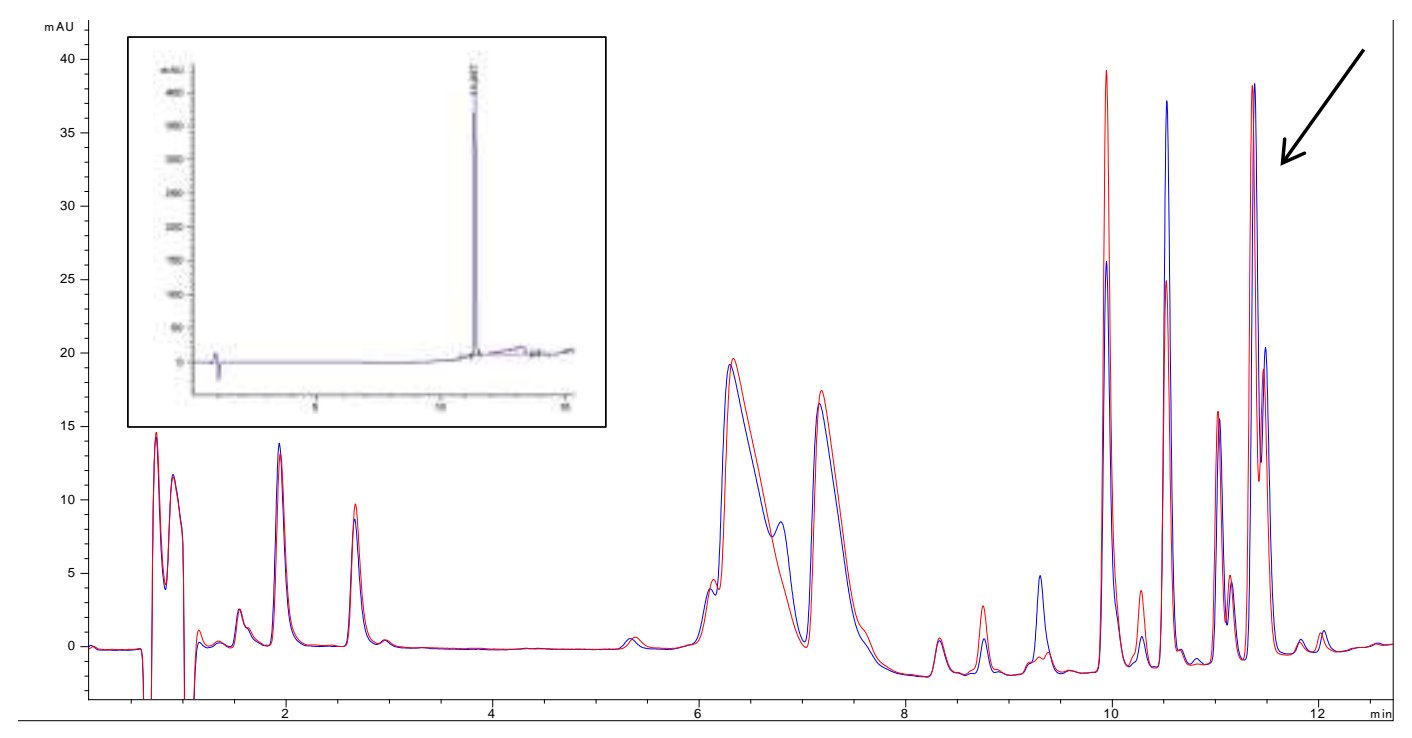

Figure 1: Overlaid LC-UV trace $(254 \mathrm{~nm})$ of $10 \mu \mathrm{g} / \mathrm{mL}$ Nevirapine $(37 \mu \mathrm{m})$, indicated by an arrow, reacted with $100 \mu \mathrm{M} \mathrm{NaOCl}(\mathrm{pH} 8)$ after one minute (blue trace) and 24 hours (red trace). The figure inset shows the LC-UV trace of unreacted Nevirapine $(10 \mu \mathrm{g} / \mathrm{mL}$ in phosphate buffer).

The reactivity of Nevirapine in the LC-UV data was validated by monitoring the intensity of the extracted $m / z 267$ ion (Nevirapine pseudomolecular ion) in LC-MS experiments and data were found to be comparable to LC-UV results. The extent of reaction was found to be dependent on $\mathrm{NaOCl}$ concentration as well as $\mathrm{pH}$. The $37 \mu \mathrm{M}$ Nevirapine was exhausted in as little as one minute when treated with $500 \mu \mathrm{M} \mathrm{NaOCl}$ in the buffered as well as unbuffered reactions. In the basic reaction ( $\mathrm{pH}$ 8) with $200 \mu \mathrm{M} \mathrm{NaOCl}$ the Nevirapine is undetectable at 1 minute whereas it remains at a low level in the $\mathrm{pH} 5.8$ and unbuffered reactions (Figure S1).

Although the reaction was found to be stable over time, it was found that $\mathrm{pH}$ greatly affected the reaction's speed well as the nature of the reaction products. LC-UV analysis (Figure S2) showed that a variety of distinct products were formed under basic and acidic conditions. In the mid-range concentration reactions $(37 \mu \mathrm{M})$ Nevirapine was found to be resistant to degradation at the levels of chlorine typically used in WWTWs with up to $50 \%$ of the Nevirapine remaining intact after 24 hours when treated with a 5 fold molar excess of $\mathrm{NaOCl}$. The concentration of Nevirapine in the samples were however much higher than what could be expected to be found 
in the environment. The reactions were found to occur fastest at $\mathrm{pH} 8$, although all reactions occurred rapidly and stabilised after one minute. It is also important to note that these experiments were carried out in a buffer with no other organic components.

As is the case with the chlorination of many pharmaceuticals, the kinetics of the Nevirapine reaction are first order with respect to each reactant, with second order overall (Deborde and von Gunten, 2008). Low Nevirapine $(2 \mu \mathrm{M})$ concentrations treated with 10 fold free available chlorine (FAC) were utilised to simulate realistic environmental conditions and determine reaction kinetics. The reactions started within 10 seconds (the earliest measurement) and proceeded to completion with the assumption that free available chlorine (FAC) was in excess. The reaction of Nevirapine (NVP) with $\mathrm{NaOCl}$ as FAC can be described by the following equations,

$$
\begin{aligned}
& \frac{\mathrm{d}[\mathrm{NVP}]}{\mathrm{d} t}=-\kappa[\mathrm{FAC}][\mathrm{NVP}] \\
& \frac{\mathrm{d}[\mathrm{NVP}]}{\mathrm{d} t}=-\kappa_{o b s} .[\mathrm{NVP}] \\
& \ln \left(\frac{[\mathrm{NVP}]_{t}}{[\mathrm{NVP}]_{0}}\right)=-\kappa_{o b s} \cdot t
\end{aligned}
$$

where $[N V P]$ is the total concentration of Nevirapine and $[F A C]$ is the concentration of free available chlorine (in excess). $\kappa$ is the second-order rate constant and the observed pseudo first-order rate constant is $\kappa_{o b s}$, which was calculated based the slope of the linear component of the graph of equation (3); with $\kappa_{o b s}=\kappa[F A C]$ and $[F A C]=[F A C]_{0}$. The rates at various $\mathrm{pH}$ conditions at $\mathrm{NaOCl}$ concentrations similar to WWTW are shown in Table 1 as lower limit second order rate constants, as the reactions occurred too rapidly to measure in a batch format. 
Table 1: Pseudo first order $\kappa_{\mathrm{obs}}$ and lower limit second-order Rate Constants, $\kappa(\mathrm{M}-1 . \mathrm{s}-1)$, for nevirapine (2 $\left.\mu \mathrm{M}\right)$ reacted with $20 \mu \mathrm{M}$ free available chlorine from $\mathrm{NaOCl}$ with phosphate buffer (pH 5.8 or 8 ) and without buffer.

\begin{tabular}{|l|l|l|}
\hline Sample & Pseudo first order $\kappa_{\text {obs }}$ & Second-order Rate Constants, $\boldsymbol{\kappa}\left(\mathbf{M}^{-1} \cdot \mathbf{s}^{-1}\right), 20 \mu$ M FAC \\
\hline $\mathrm{pH} \mathrm{5.8} 8^{*}$ & 0.0008 & $4.0 \times 10^{1}$ \\
\hline $\mathrm{pH} 8$ & 0.0204 & $1.02 \times 10^{3}$ \\
\hline Unbuffered & 0.1175 & $5.88 \times 10^{3}$ \\
\hline
\end{tabular}

* The Nevirapine is not consumed entirely in this reaction.

The reaction occurred most rapidly in the unbuffered reactions, followed by reactions at basic $\mathrm{pH}$, in acidic buffer and in WWTW effluent respectively. In the basic reaction the Nevirapine was completely consumed after $90 \mathrm{~s}$, whereas in the acidic reaction the Nevirapine consumption ceases at $110 \mathrm{~s}$, with up to $80 \%$ Nevirapine remaining (Figure S3). The unbuffered reaction proceeds most rapidly, with total Nevirapine consumption. This is most likely due to the fact that the continued reactivity of the transformation products is unencumbered by the buffer and its resulting effect on compound speciation.

The wastewater matrix composition can greatly affect the efficacy of pharmaceutical transformation due to the chlorine demand exerted by dissolved organic molecules, nitrites and ammonia (Lee and von Gunten, 2010). During wastewater treatment, Nevirapine degradation would most likely be even less effective due to the increased chlorine demand caused by these molecules in the wastewater. Where, wastewater was used as a reaction matrix for kinetics studies, it was found that $95 \%$ of the Nevirapine remained intact when treated with a 10 fold molar excess of chlorine. A second order rate constant could not be determined as the chlorine did not remain in excess due to the demand placed on it by dissolved organic matter, 
$\mathrm{pH}$ was found to significantly affect the extent of Nevirapine degradation in all three reaction formats tested in this work, with greater reactivity seen at a high $\mathrm{pH}$ than in acidic reactions. The $\mathrm{OCl}^{-}$species dominates at a basic $\mathrm{pH}$ and is a weaker oxidizer than $\mathrm{HOCl}$. The increased reactivity of Nevirapine when $\mathrm{OCl}^{-}$is predominant may therefore be as a result of the speciation (i.e. anionic, cationic or neutral) of Nevirapine.

During wastewater treatment, chlorine is utilised as a disinfectant; and optimal disinfection is achieved when the $\mathrm{HOCl}$ species dominates (at low $\mathrm{pH}$ ). As we have demonstrated these are the exact opposite conditions required for effective Nevirapine removal. The concept of reactivity related to $\mathrm{pH}$ is further confounded, as it was found that some compounds are effectively removed at low pH (e.g. sulfamethoxazole) while others (e.g. ciprofloxacin) are better removed at a high $\mathrm{pH}$ where the reaction is dependent on reagent speciation ( $\mathrm{Li}$ and Zhang, 2012). These data provide credence to earlier research in that Nevirapine is one of the most ubiquitously occurring ARVs in the environment (Wood et al., 2015).

\subsection{LC-qTOF Analysis}

Accurate masses generated from analyses of various chlorination reactions were used to generate formulae for each mass. Formulae were then used to propose theoretical structures for the most prominent reaction products using the Nevirapine skeleton as a starting point (Table 2).

MS/MS spectra for each of these structures were then compared to theoretical mass spectra generated using Molecular Structure Correlator (MSC). When multiple proposed structures existed for a compound, MSC scores were utilised to discriminate between candidates. Only structures with scores greater than $98 \%$ (intact) and $90 \%$ (for fragments) were accepted for further consideration. 
Table 2: Accurate mass measurements and proposed structures for the most prominent chlorination reaction products of Nevirapine. Theoretical structures were compared to MS/MS data using Agilent Molecular structure Correlator.

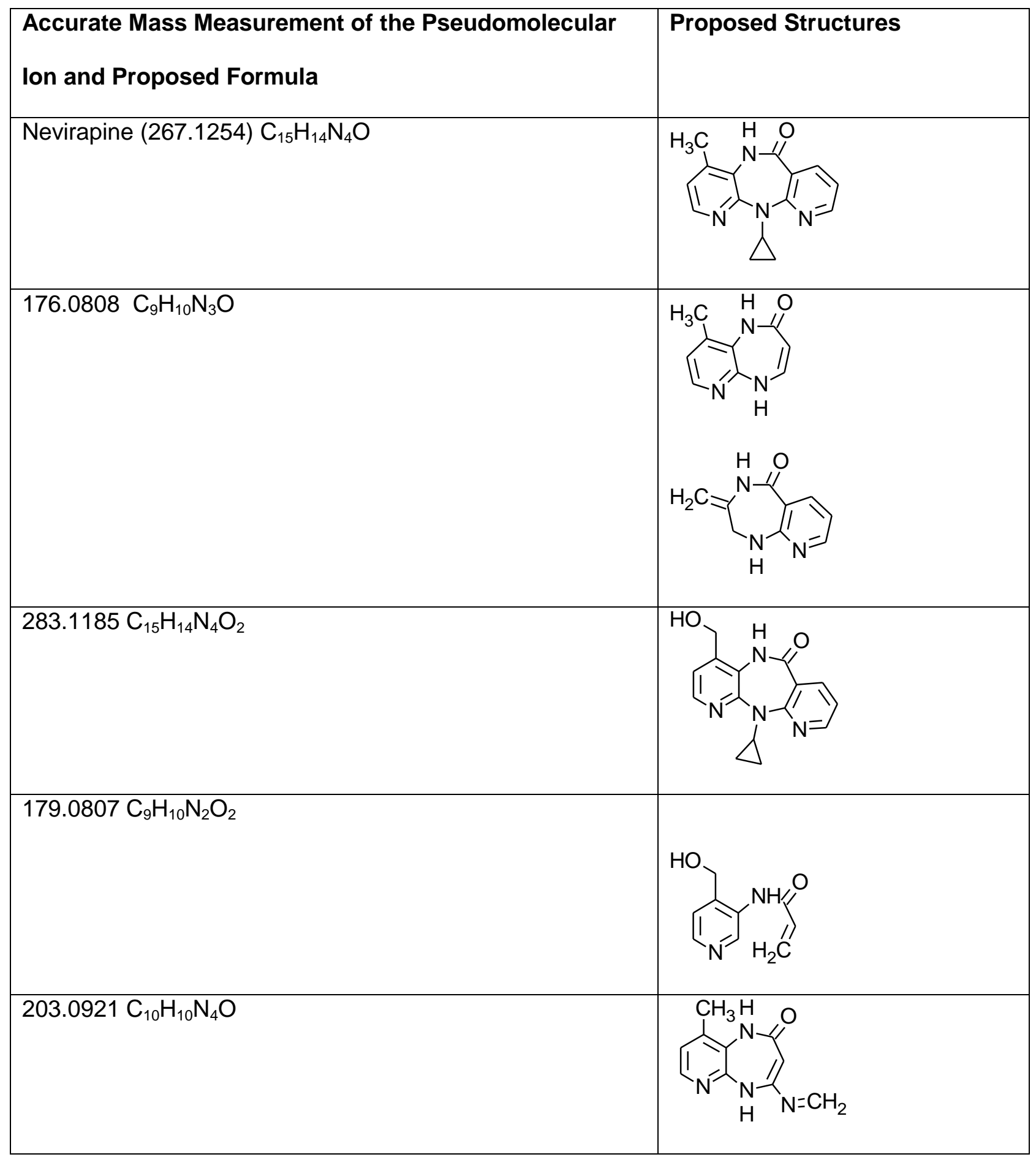




$301.1284 \mathrm{C}_{15} \mathrm{H}_{16} \mathrm{~N}_{4} \mathrm{O}_{3}$

Data from the large scale as well as the 1 minute chlorination reactions were analysed to identify abundant and unique chemical entities (not present in the system or controls). The compounds' masses, retention times, MS/MS spectra and proposed formulae were collated into a searchable database containing 42 putative compounds (Table S1), using PCDL Manager (Agilent). It was found that several molecules yielding highly similar accurate mass measurements existed that were only distinguishable by their retention times. These are most likely stereoisomers as it was found that a variety of potential nevirapine reaction products share the same mass.

Although the chlorination of Nevirapine at chlorine levels similar to those used in WWTWs yielded a wide variety of major and minor reaction products, certain well described functional groups within the molecule may be used to predict transformation. Nevirapine contains a tertiary 
amine, a moiety which reacts with chlorine as described in various studies (Prütz, 1998; Mitch and Schreiber, 2008; Shah et al., 2011; Selbes et al., 2012). Using these models the loss of cyclopropane as seen in a number of the DTPs may be explained (Figure 2). Unfortunately though, this may not be applied to all such compounds, as highlighted by Deborde and von Gunten (2008) in which Ciprofloxacin and Enrofloxacin (both contain a similar cyclopropane moeity) react preferentially with chlorine at another amine.

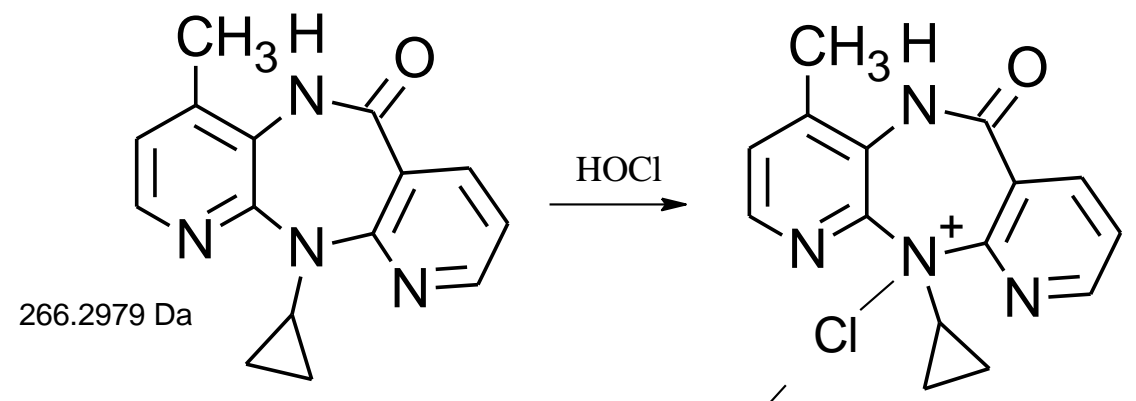<smiles>Cc1ccnc2c1NC(=O)c1cccnc1N2</smiles>

226.234 Da

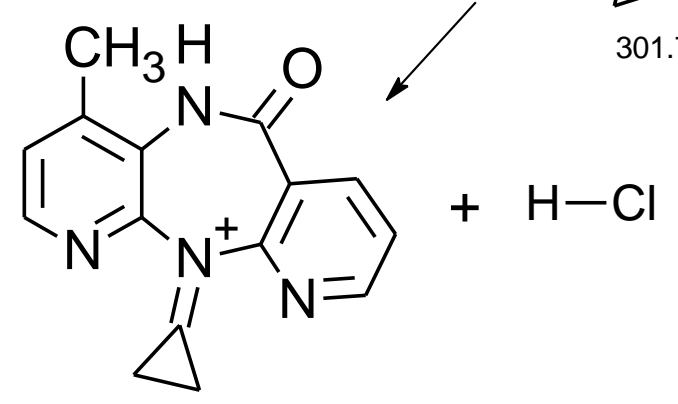

265.2894 Da

Figure 2: Proposed scheme for the reaction of the Nevirapine tertiary amine during chlorination.

The molecule $\mathrm{m} / \mathrm{z} 226$ was detected a number of times in the analyses (of the chlorination reactions) but since it is one of the major MS/MS and CID fragmentation products of Nevirapine and its transformation products, its presence as a standalone molecule could not be confirmed with confidence in environmental samples, i.e. it may be a mass spectrometric fragmentation product and not an intact molecule. 


\subsection{Detection of Nevirapine and its chlorination products in the environment}

The SPE technique utilised here was chosen for its universality. Unfortunately limits of detection and quantitation for the method could not be performed as reaction mixtures consisting of multiple components were used as standards. However, this work is largely qualitative with a lower limit of detection defined as an amount providing a signal to noise ratio of 3 .

Samples from every major river and water body in South Africa (Table S2) were screened against a database of the most ubiquitous Nevirapine chlorination reaction products. From these data (Table S3), positive identification in the environment was only accepted if the mass of the pseudomolecular ion, the retention time and MS/MS spectra matched to the compound present in the in vitro chlorination reactions. As anticipated, the compounds were only detected in samples taken close to WWTWs in dense human settlements.

Full scan mass spectra provided a wealth of information regarding a particular sample and intense ions were automatically fragmented, in a separate injection, to provide MS/MS data.

Fragmentation energy was set automatically based on the precursor's mass. Many of the

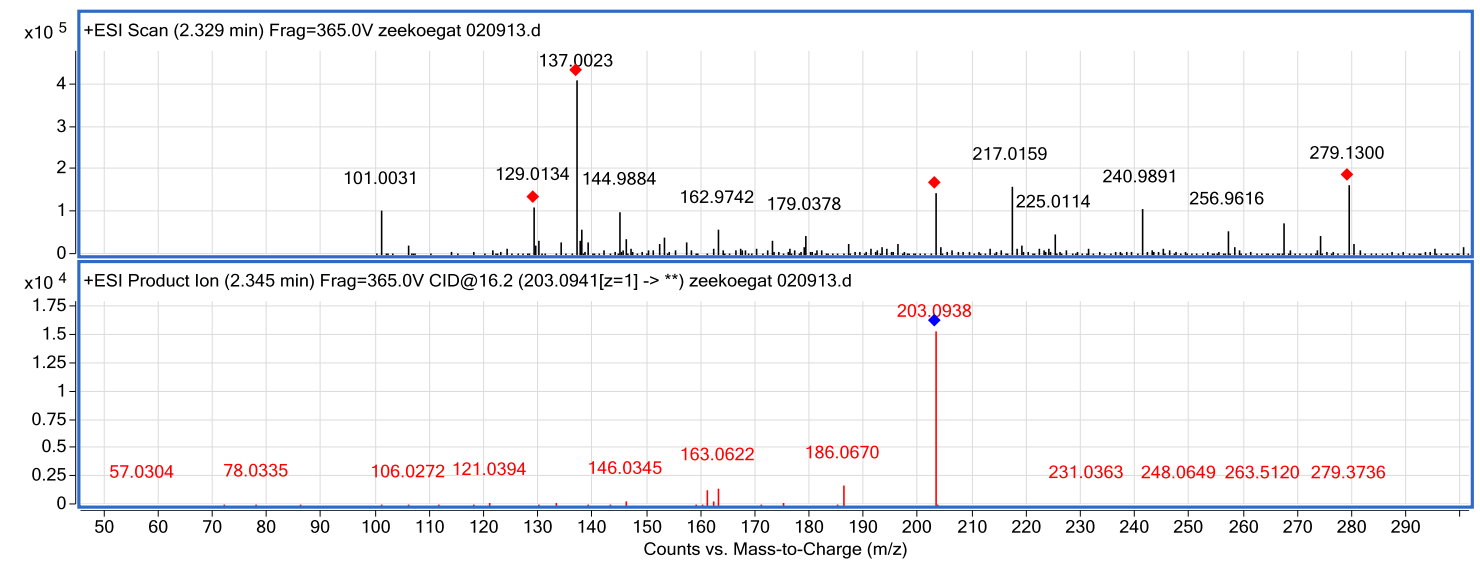

Figure 3: Full scan ESI spectrum (top) and ESI auto-MS/MS spectrum of $\mathrm{m} / \mathrm{z} 203.0941+-0.01$ (bottom) of an SPE extract of water taken from the Zeekoegat WWTW discharge, analysed by UHPLC-QTOF (retention time: 2.239 minutes). Red squares (top) indicate ions automatically chosen for MS/MS and the blue square (bottom) indicates the precursor ion, fragmented at $16.2 \mathrm{eV}$. 
prominent chlorination products were detected in the environment. As an example, at the Zeekoegat sampling site, the compound with the $m / z 203.0938$ was detected (Figure 3).

The QTOF operates in "auto MS/MS" mode in which intense ions are selected during full scan mode for MS/MS fragmentation. The instrument selects the collision energy to use on a case by case basis depending on the particular ion's mass. Using this approach accurate mass measurements of the intact species as well as the resulting fragments (and their ratios) may be utilised to compare samples to analytical standards; or even generate structures by interpretation.

The MS/MS spectrum for this compound was predicted by the Molecular Structure Correlator (Agilent) software (Table 3). Although the software assumes that the pseudomolecular ion is fragmented fully, when proposing the ions' nominal intensities, the ratio between the fragment ions agrees with the measured standard (Figure 4). Similarly, for this compound, and many like it, the ion ratios measured in the environment, match the "standards" generated in the laboratory. 
Table 3: Measured mass spectrum compared to theoretical fragmentation generated for the MS/MS of $m / z$ 203.0941 by Molecular Structure Correlator (Agilent) with the difference between measured and proposed masses and structures (grey text indicates fragmentation); for the $\mathbf{1 0}$ most intense ions.

\begin{tabular}{|l|l|l|l|l|}
\hline Measured & Nominal & Proposed & Mass \\
$\mathbf{m} / \mathbf{z}$ & Intensity & Formula & Proposed Structure \\
$(\mathbf{p p m})$
\end{tabular}




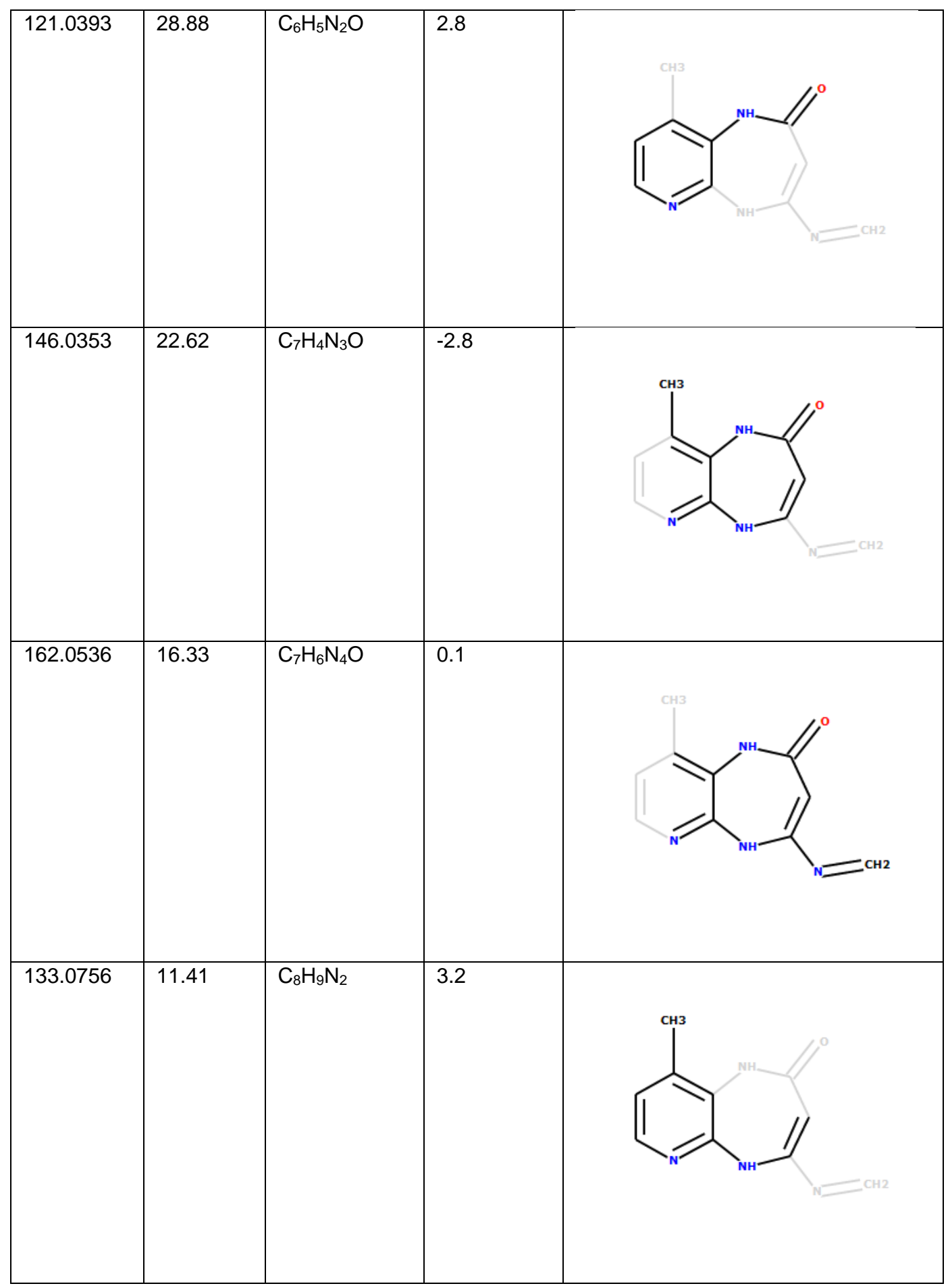




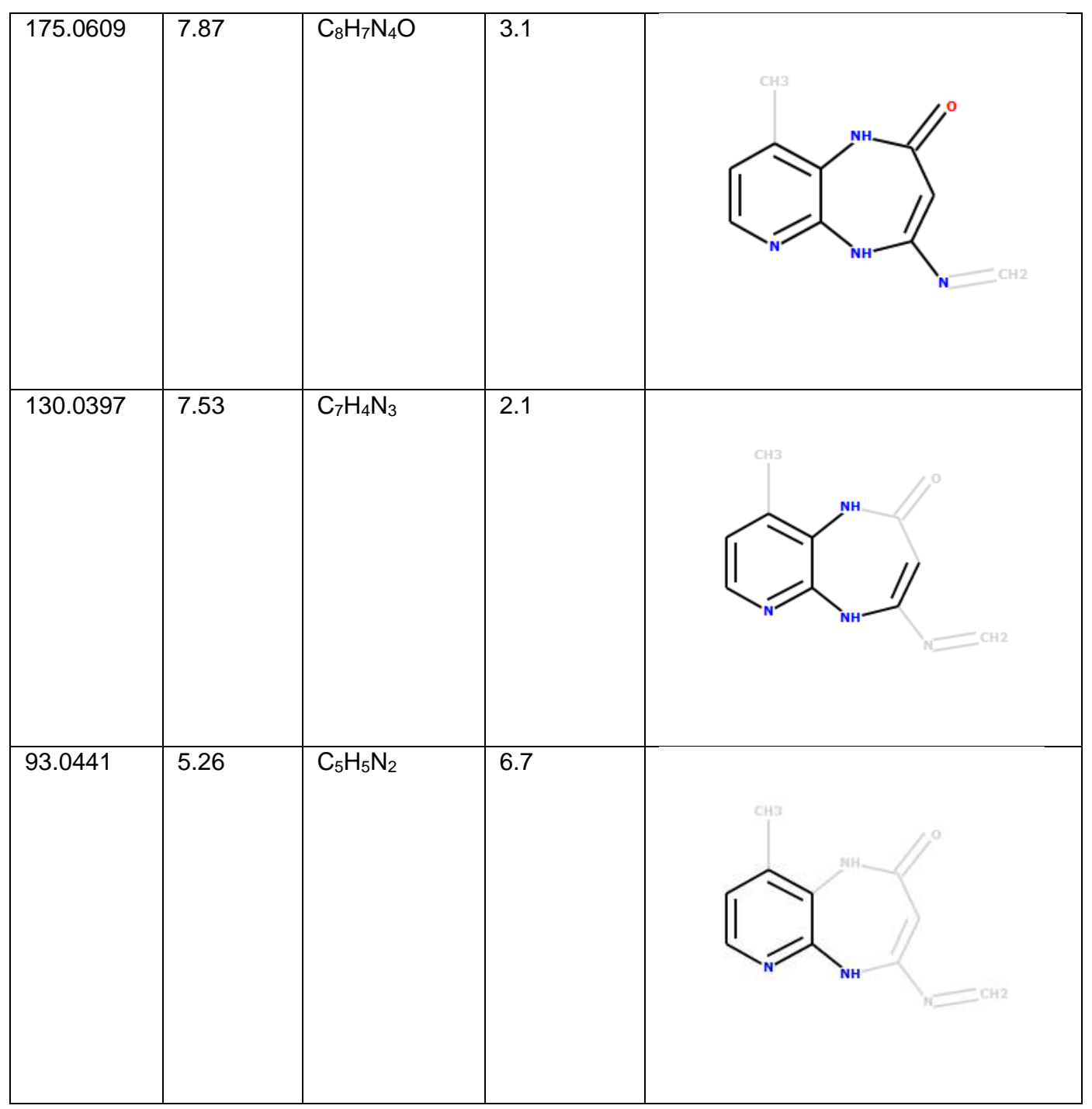




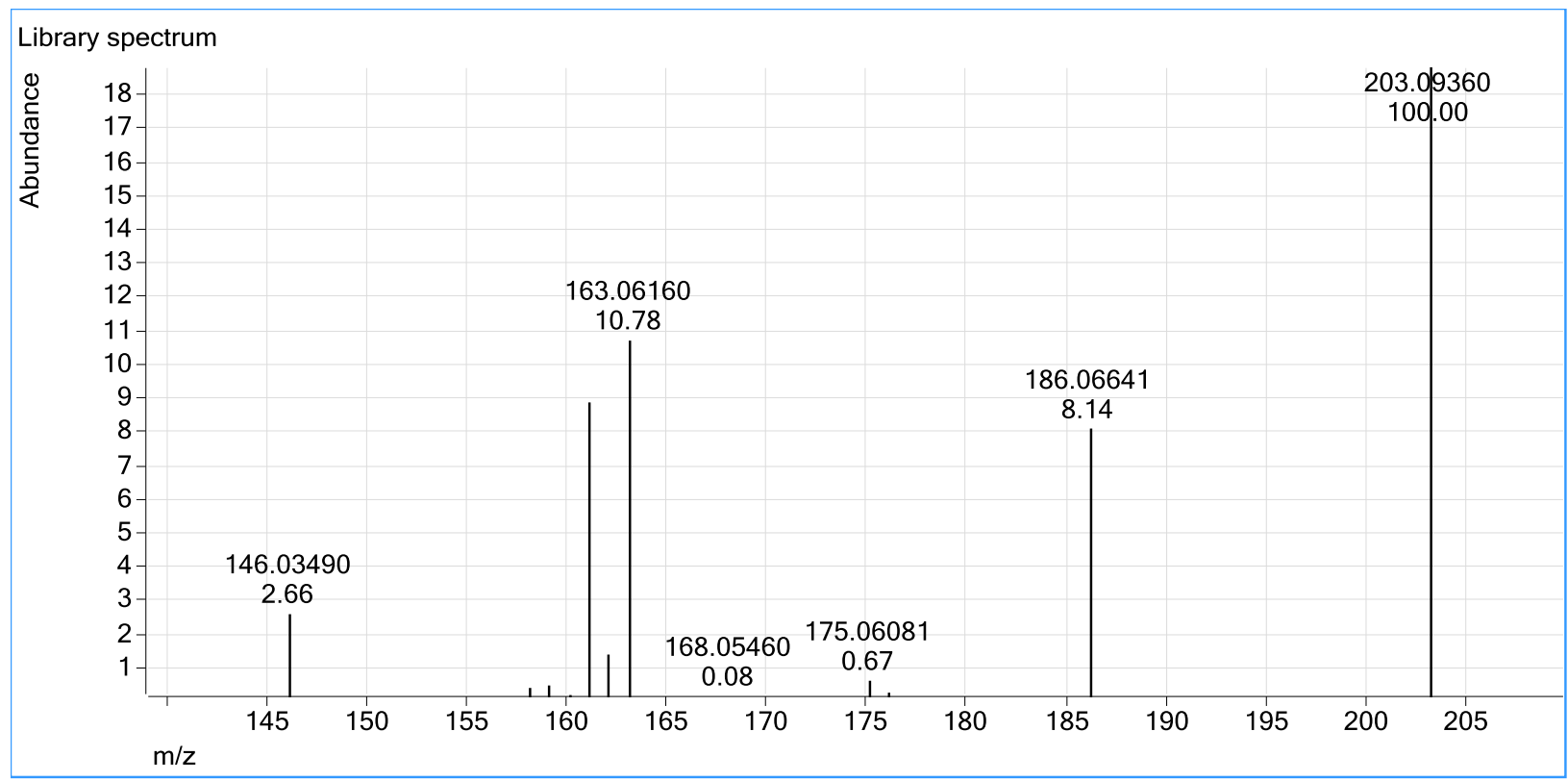

Figure 4: ESI auto-MS/MS spectrum of $\mathrm{m} / \mathrm{z} 203.0941+-0.01$, from a 1 minute chlorination reaction of Nevirapine, pH 8, $200 \mu \mathrm{M} \mathrm{NaOCl}$; analysed by UHPLC-QTOF. The "standard" spectrum was exported from PCDL Manager (Agilent).

It was found, and it is self-evident, that the DTPs are more prevalent in highly populated areas that are near WWTWs. The prevalence of these compounds could also be related to Nevirapine concentration, in that samples that contained lower levels of Nevirapine were found to not contain detectable amounts of the DTPs. The majority of the DTPs were detected in the Roodeplaat system (Table 4), which is influenced by two of the three WWTWs that were sampled in this research. The environmental prevalence (Table S3), is therefore relatively low, compared to the ubiquitous distribution of the parent molecule (30 locations across South Africa were sampled and it was found that Nevirapine is detectable at the majority of the sites).

The concept of the minimal criteria required for identification of a compound by mass spectrometry is a widely discussed topic, as inter-laboratory LC-MS comparison is not always fully possible. This is because variability in instrumentation type and conditions would lead to 
Table 4: An excerpt of Nevirapine chlorination products detected by positive ESI UHPLC-QTOF analysis of SPE extracts of surface water samples from the Roodeplaat Dam.

\begin{tabular}{|c|c|c|c|c|c|c|}
\hline Sampling Location (GPS Coordinates) & $m / z$ & RT & $\begin{array}{l}\text { RT Diff } \\
(\text { Tgt })^{*}\end{array}$ & $\begin{array}{l}\text { Diff (DB, } \\
m D a)^{* *}\end{array}$ & Mass & $\begin{array}{l}\text { Proposed } \\
\text { Formula*** }\end{array}$ \\
\hline $\begin{array}{l}\text { Roodeplaat Dam Outflow (-25.608244, } \\
\text { 28.367231) }\end{array}$ & 160.0854 & 3.222 & 0.006 & 0.45 & 159.0783 & $\mathrm{C}_{9} \mathrm{H}_{9} \mathrm{~N}_{3}$ \\
\hline $\begin{array}{l}\text { Roodeplaat Dam (-25.623345, } \\
\text { 28.349842) }\end{array}$ & 160.087 & 3.18 & -0.036 & -0.84 & 159.0795 & $\mathrm{C}_{9} \mathrm{H}_{9} \mathrm{~N}_{3}$ \\
\hline $\begin{array}{l}\text { Roodeplaat Dam (-25.626404, } \\
\text { 28.345692) }\end{array}$ & 160.0855 & 3.238 & 0.022 & 0.9 & 159.0778 & $\mathrm{C}_{9} \mathrm{H}_{9} \mathrm{~N}_{3}$ \\
\hline $\begin{array}{l}\text { Roodeplaat Dam Outflow (-25.608244, } \\
\text { 28.367231) }\end{array}$ & 160.0858 & 3.225 & 0.009 & 1.4 & 159.0773 & $\mathrm{C}_{9} \mathrm{H}_{9} \mathrm{~N}_{3}$ \\
\hline Pienaars River (-25.678677, 28.357116) & 188.0825 & 4.662 & -0.061 & -0.49 & 187.0756 & $\mathrm{C}_{10} \mathrm{H}_{9} \mathrm{~N}_{3} \mathrm{O}$ \\
\hline $\begin{array}{l}\text { Roodeplaat Dam (-25.618238, } \\
\text { 28.358642) }\end{array}$ & 188.0822 & 4.673 & -0.05 & -1.69 & 187.0768 & $\mathrm{C}_{10} \mathrm{H}_{9} \mathrm{~N}_{3} \mathrm{O}$ \\
\hline $\begin{array}{l}\text { Roodeplaat Dam (-25.618238, } \\
\text { 28.358642) }\end{array}$ & 188.0823 & 4.656 & -0.067 & -1.65 & 187.0767 & $\mathrm{C}_{10} \mathrm{H}_{9} \mathrm{~N}_{3} \mathrm{O}$ \\
\hline Pienaars River (-25.678677, 28.357116) & 317.0813 & 7.234 & -0.017 & -1.13 & 316.0742 & $\mathrm{C}_{15} \mathrm{H}_{13} \mathrm{Cl} \mathrm{N}_{4} \mathrm{O}_{2}$ \\
\hline $\begin{array}{l}\text { Roodeplaat Dam (-25.618238, } \\
\text { 28.358642) }\end{array}$ & 203.0922 & 2.288 & -0.007 & 1.15 & 202.084 & $\mathrm{C}_{10} \mathrm{H}_{10} \mathrm{~N}_{4} \mathrm{O}$ \\
\hline $\begin{array}{l}\text { Roodeplaat Dam (-25.626404, } \\
\text { 28.345692) }\end{array}$ & 351.1577 & 5.312 & -0.019 & 1.62 & 175.0737 & $\mathrm{C}_{9} \mathrm{H}_{9} \mathrm{~N}_{3} \mathrm{O}$ \\
\hline $\begin{array}{l}\text { Zeekoegat WWTW Outflow (-25.624620, } \\
\text { 28.341890) }\end{array}$ & 319.1144 & 9.616 & -0.026 & 2.42 & 296.1254 & $\mathrm{C}_{16} \mathrm{H}_{16} \mathrm{~N}_{4} \mathrm{O}_{2}$ \\
\hline $\begin{array}{l}\text { Roodeplaat Dam (-25.626404, } \\
\text { 28.345692) }\end{array}$ & 319.1142 & 9.632 & -0.009 & 2.63 & 296.1252 & $\mathrm{C}_{16} \mathrm{H}_{16} \mathrm{~N}_{4} \mathrm{O}_{2}$ \\
\hline
\end{tabular}

${ }^{*}$ RT Diff (Tgt) - The difference between the measured retention time and that of the standard (minutes)

** Diff (DB, mDa) The difference between the measured mass and that of the true mass of the "standard"

*** Proposed formula, generated by MassHunter Qual (Agilent)

variability of data generated for identical compounds (Rivier, 2003). Therefore in this work, even though DTP "standards" were not isolated and characterised in pure form and only analysed as a mixture, a positive identification of a DTP in the environment was only accepted 
if: retention time matched within $0.1 \mathrm{~min}, \mathrm{MS} / \mathrm{MS}$ spectra matched, the accurate mass difference was no greater than $1 \mathrm{ppm}$ and that the overall MassHunter match factor was greater than $80 \%$ (a value that encompasses all of the aforementioned factors).

It is exceptionally important to bear in mind that the lower molecular weight species described during the chlorination reactions and subsequently found in surface water, may not necessarily originate from the degradation of Nevirapine. This is because the probability of a shared feature between Nevirapine and another molecule increases as the fragment size decreases.

\subsection{Large Scale Preparation and Separation of Chlorination Reaction Products}

The small-scale chlorination studies could not be scaled-up to maintain the molar ratio between nevirapine and $\mathrm{NaOCl}$, as it would have lead to very high volume reactions; and it was for this reason that the products of the reactions differed significantly. Compounds identified in the small scale reactions were not present in the scaled-up versions and visa-versa. Similarly, a plethora of novel compounds were found in the scaled-up reactions that were not present in the small scale reactions. This phenomenon could be attributed to not only the transience of some of the reaction products, but also the low concentrations of the small scale reactions. This is important since many researchers utilise this small scale in vitro approach to simulate an industrial process (wastewater treatment); and it may not provide a true reflection of the myriad of potential reactions that pharmaceuticals undergo in this situation.

A total of 45 and 29 fractions were prepared for the basic and acidic reactions, respectively. From UHPLC-QTOF analysis it was found that each fraction contained multiple compounds. This is due to the high levels of similarity between them, as they all arose from the same parent molecule. Chromatographic separation of these highly similar compounds would therefore prove 
to be challenging. Nevirapine was also present in a number of fractions and its presence was borne in mind when attributing antiviral activity to a particular fraction.

Nevirapine, and subsequently the total chlorination reaction was found to be highly insoluble in water and the majority of commonly used laboratory solvents. The varying levels of solubility of the reaction components further confounds chromatographic purification.

\subsection{In Vitro Toxicity and Activity}

The total and preparative chromatography samples of both acidic and basic chlorination reactions of Nevirapine were subjected to toxicity and activity studies, in vitro. The concentration at which $50 \%$ of the cells' growth is inhibited $\left(\mathrm{IC}_{50}\right)$, is inversely proportional to the level of toxicity of a test compound. Thus, a low $\mathrm{IC}_{50}$ value is indicative of a high level of toxicity. This is determined by comparing the spectrophotometric absorbance, generated through the measurement of MTS, of the test sample to an untreated control. The ratio is then presented as a percentage to indicate cell survival. The total reactions were much less toxic than Nevirapine (Table 5) and none of the preparative fractions were found to be more toxic than the parent molecule in 293T cells. 
Table 5: Inhibitory concentrations $(\mu \mathrm{g} / \mathrm{mL})$ at which $50 \%$ of $293 \mathrm{~T}$ cells in vitro are killed, as determined by MTS assay. The total chlorination reactions of Nevirapine (in basic or acidic phosphate buffer; pH 8 or 5.8 respectively) as compared to a Nevirapine control. Standard deviation presented in brackets.

\begin{tabular}{|l|l|}
\hline & $\begin{array}{l}\text { Average } \\
\mathrm{IC}_{50} \\
(\mu \mathrm{g} / \mathrm{mL})\end{array}$ \\
\hline Nevirapine basic reaction & $73.7(0.4)$ \\
\hline Nevirapine acid reaction & $34.1(2.1)$ \\
\hline Nevirapine control & $0.03(0.01)$ \\
\hline
\end{tabular}

That is not to say however that the compounds would not produce toxicity in another fashion (e.g. hepatotoxicity, carcinogenicity etc.) or exhibit novel aspects environmental toxicity. This should be determined by further in vitro studies. But, this provides a heartening indication that the chlorination products do not represent yet another anthropogenic source of toxicity that is being discharged into the environment.

The inhibition of viral replication was determined in a single cycle of infection. Virus-like particles were used that contain HIV-1 subtype C reverse transcriptase, integrase and protease, as well as the RNA transcript of the firefly luciferase protein. Once the virus infects the cell, the firefly RNA is reverse transcribed by the HIV-1 reverse transcriptase to a complementary DNA (cDNA) and integrated into the host cell's chromosomal DNA by HIV-1 integrase. Upon integration, the firefly luciferase gene is expressed to produce active firefly luciferase that can quantified by measuring its bioluminescence. In the absence of inhibitors, this signal is directly proportional to the number of infectious virus particles present in the initial inoculum. Since inhibitors (e.g. DTPs) decrease the number of firefly luciferase gene copies that are integrated into the host's genome, a decrease in the amount of bioluminescence will also be observed. The 
bioluminescence ratio between an exposed sample and an unexposed control is presented as a percentage to indicate the effect of a test compound on viral activity.

During antiviral activity studies a number of the preparative fractions (Tables S4 and S5) showed antiviral activity. The majority of these however can be attributed to the presence of intact Nevirapine. This is because many of the novel compounds share structural similarity with Nevirapine and because of Nevirapine's insolubility, they could not be separated effectively by preparative chromatography. This could be circumvented by comparing the ratio of the UHPLCQTOF extracted ion ( $m / z$ 267.1) peak area to the antiviral activity intensity (Figure S4) between the fractions. The fractions that had antiviral properties not attributed to Nevirapine could then be identified as outliers (i.e. an increase in antiviral activity not associated with an equivalent increase in Nevirapine concentration).

Since many of these compounds either share the Nevirapine "backbone" or are only slightly modified, it is reasonable to speculate that they would also share Nevirapine's structure activity relationship. Nevirapine displayed an $\mathrm{IC}_{50}$ value of $0.03 \mu \mathrm{g} / \mathrm{mL}$, which is substantially lower than the levels at which the total chlorination reaction showed antiviral properties. The various purified fractions however had wide ranging $\mathrm{IC}_{50}$ values $(0.02$ to $20 \mu \mathrm{g} / \mathrm{mL}$ ). Higher values may be due to reduced activity properties in the particular molecules or due to the fact that the compounds were not tested in pure form; thereby providing aberrant compound mass-to-activity results

Once these compounds are fully characterised by mass spectrometry (e.g. MS ${ }^{n}$ studies) and Nuclear Magnetic Resonance (NMR), they may be synthesised in their pure form. This will lead to a deeper understanding of their mechanism of action. 


\section{Conclusion}

From kinetics studies, where chlorine was in excess, it was found that Nevirapine would not be degraded effectively during wastewater treatment because of: increased chlorine demand by dissolved organic matter and reduced degradation at the acidic $\mathrm{pH}$ used in wastewater treatment. The latter is most likely due to the speciation of the Nevirapine molecule. This serves to explain the ubiquitous environmental prevalence in South African surface water, as shown in earlier research (Wood et al., 2015). Although the molecule is relatively persistent, in this work it was shown that Nevirapine is still subject to modification by chlorination, producing a number of DTPs, and degrades entirely at a basic $\mathrm{pH}$.

Through a UHPLC-QTOF analysis of South African surface water it was shown that the DTPs described from in vitro analysis are present in the environment. But, the national prevalence of these compounds is exceptionally low since the parent molecule is only found in trace amounts. This is because only a small proportion of an already low concentration of Nevirapine reacts to form these compounds and the distribution is further limited due to the dilution of WWTW discharge.

The chlorination reaction of Nevirapine was scaled up in order to isolate the DTPs identified in nature and in the small-scale stirred reactions; yet it was found that the scale of the reaction affects the nature of the reaction products. This serves to highlight that laboratory scale chlorination may not always be truly representative of industrial wastewater treatment, in that compounds identified in laboratory-scale reactions may not be present in wastewater purification scale reactions and vice versa. This is largely due to concentration differences between the two as well as the addition of a number of uncontrollable variables (e.g. reactive chemicals) in wastewater. With that said though, selected compounds that were identified in the 
small scale reactions (lower total concentration of both Nevirapine and $\mathrm{NaOCl}$ ) were incorporated into a database and subsequently detected in WWTW effluent.

Through in vitro toxicity and activity testing it was found that none of the nevirapine DTPs are more toxic than the parent molecule. It was however also found that antiviral activity is retained in some of the isolated fractions. Whether this can be attributed to a single molecule or through synergistic effects will only be clarified once individual DTPs are isolated or synthesized.

It is important to consider the fact that pharmaceuticals may be modified and still retain biological activity. It is therefore clear that we need to consider the total impact of not only discharging pharmaceuticals but also their reaction products into the environment. The wastewater treatment process should be scrutinized to not only remove pharmaceuticals through chemical degradation but also their resulting byproducts. Various authors have noted that pharmaceuticals may form biologically active transformation products during wastewater purification (Dodd et al., 2009; Escher and Fenner, 2011; Mestankova et al., 2012; Keen and Linden, 2013). Further investigation into the purification and characterization of the reaction products identified in this work is required in order to obtain a clear picture of how the disinfection of these types of compounds affect the environment.

\section{Acknowledgements:}

Christoph Mueller of Agilent Technologies for his kind help on the UHPLC-QTOF method development.

The 293T cells were obtained through the NIH AIDS Reagent Program, Division of AIDS, NIAID, NIH: 293 from Dr.Andrew Rice. 


\section{Funding Source:}

We would like to gratefully acknowledge the South African Military Health Services for funding this research. The funding agency did not play a role in the study design or data interpretation.

\section{References}

Barltrop, J.A., Owen, T.C., Cory, A.H., Cory, J.G., 1991. 5-(3-carboxymethoxyphenyl)-2-(4, 5dimethylthiazolyl)-3-(4-sulfophenyl) tetrazolium, inner salt (MTS) and related analogs of 3-(4, 5dimethylthiazolyl)-2, 5-diphenyltetrazolium bromide (MTT) reducing to purple water-soluble formazans as cell-viability indicators. Bioorganic $\backslash \&$ Medicinal Chemistry Letters 1 (11), 611-614.

Bedner, M., MacCrehan, W.A., 2006. Transformation of acetaminophen by chlorination produces the toxicants 1, 4-benzoquinone and $\mathrm{N}$-acetyl-p-benzoquinone imine. Environmental science $\& \&$ technology 40 (2), 516-522.

Bulloch, D.N., Nelson, E.D., Carr, S.A., Wissman, C.R., Armstrong, J.L., Schlenk, D., Larive, C.K., 2015. Occurrence of Halogenated Transformation Products of Selected Pharmaceuticals and Personal Care Products in Secondary and Tertiary Treated Wastewaters from Southern California. Environmental Science $\ \&$ Technology.

Coovadia, H.M., Brown, E.R., Fowler, M.G., Chipato, T., Moodley, D., Manji, K., Musoke, P., StranixChibanda, L., Chetty, V., Fawzi, W., others, 2012. Efficacy and safety of an extended nevirapine regimen in infant children of breastfeeding mothers with HIV-1 infection for prevention of postnatal HIV-1 transmission (HPTN 046): a randomised, double-blind, placebo-controlled trial. The Lancet 379 (9812), 221-228. 
Deborde, M., von Gunten, U., 2008. Reactions of chlorine with inorganic and organic compounds during water treatment-Kinetics and mechanisms: A critical review. Water research 42 (1), 13-51.

Dodd, M.C., Kohler, H.-P.E., Von Gunten, U., 2009. Oxidation of antibacterial compounds by ozone and hydroxyl radical: elimination of biological activity during aqueous ozonation processes. Environmental science $\backslash \&$ technology 43 (7), 2498-2504.

Escher, B.I., Fenner, K., 2011. Recent advances in environmental risk assessment of transformation products. Environmental science $\backslash \&$ technology 45 (9), 3835-3847.

Graham, F., Smiley, J., Russell, W., Nairn, R., 1977. Characteristics of a human cell line transformed by DNA from human adenovirus type 5. Journal of General Virology 36 (1), 59-72.

He, Y., Chen, W., Zheng, X., Wang, X., Huang, X., 2013. Fate and removal of typical pharmaceuticals and personal care products by three different treatment processes. Science of The Total Environment 447, 248-254.

Keen, O.S., Linden, K.G., 2013. Degradation of antibiotic activity during UV/H2O2 advanced oxidation and photolysis in wastewater effluent. Environmental science $\backslash \&$ technology 47 (22), 13020-13030.

Kümmerer, K., 2009. Antibiotics in the aquatic environment-a review-part II. Chemosphere 75 (4), $435-$ 441.

Lee, Y., von Gunten, U., 2010. Oxidative transformation of micropollutants during municipal wastewater treatment: comparison of kinetic aspects of selective (chlorine, chlorine dioxide, ferrate $\mathrm{VI}$, and ozone) and non-selective oxidants (hydroxyl radical). Water Research 44 (2), 555-566. 
Leopold, P., Freese, S.D., 2009. A SIMPLE GUIDE TO THE CHEMISTRY, SELECTION AND USE OF CHEMICALS FOR WATER AND WASTEWATER TREATMENT (TT 405/09).

Li, B., Zhang, T., 2012. pH significantly affects removal of trace antibiotics in chlorination of municipal wastewater. Water research 46 (11), 3703-13.

Mestankova, H., Schirmer, K., Escher, B.I., von Gunten, U., Canonica, S., 2012. Removal of the antiviral agent oseltamivir and its biological activity by oxidative processes. Environmental pollution 161, 30-35.

Mitch, W.A., Schreiber, I.M., 2008. Degradation of tertiary alkylamines during chlorination/chloramination: implications for formation of aldehydes, nitriles, halonitroalkanes, and nitrosamines. Environmental science $\backslash \&$ technology 42 (13), 4811-4817.

Mofenson, L.M., 2010. Prevention in neglected subpopulations: prevention of mother-to-child transmission of HIV infection. Clinical Infectious Diseases 50 (Supplement 3), S130-S148.

Peng, X., Ou, W., Wang, C., Wang, Z., Huang, Q., Jin, J., Tan, J., 2014. Occurrence and ecological potential of pharmaceuticals and personal care products in groundwater and reservoirs in the vicinity of municipal landfills in China. Science of The Total Environment 490, 889-898.

Petrie, B., Barden, R., Kasprzyk-Hordern, B., 2014. A review on emerging contaminants in wastewaters and the environment: Current knowledge, understudied areas and recommendations for future monitoring. Water research.

Prasse, C., Schlüsener, M.P., Schulz, R., Ternes, T.A., 2010. Antiviral drugs in wastewater and surface waters: a new pharmaceutical class of environmental relevance? Environmental science \& technology $44(5), 1728-1735$. 
Prasse, C., Stalter, D., Schulte-Oehlmann, U., Oehlmann, J., Ternes, T.A., 2015. Spoilt for choice: A critical review on the chemical and biological assessment of current wastewater treatment technologies. Water research 87, 237-270.

Prütz, W., 1998. Reactions of hypochlorous acid with biological substrates are activated catalytically by tertiary amines. Archives of biochemistry and biophysics 357 (2), 265-273.

Richardson, S.D., Plewa, M.J., Wagner, E.D., Schoeny, R., DeMarini, D.M., 2007. Occurrence, genotoxicity, and carcinogenicity of regulated and emerging disinfection by-products in drinking water: a review and roadmap for research. Mutation Research/Reviews in Mutation Research 636 (1), 178242.

Rivier, L., 2003. Criteria for the identification of compounds by liquid chromatography-mass spectrometry and liquid chromatography-multiple mass spectrometry in forensic toxicology and doping analysis. Analytica Chimica Acta 492 (1), 69-82.

Roden, N.M., Sargent, E.V., DiFerdinando Jr, G.T., Hong, J.-Y., Robson, M.G., 2015. The Cumulative Risk to Human Health of Pharmaceuticals in New Jersey Surface Water. Human and Ecological Risk Assessment: An International Journal 21 (1), 280-295.

Selbes, M., Kim, D., Ates, N., Karanfil, T., 2012. The roles of tertiary amine structure, background organic matter and chloramine species on NDMA formation. Water research.

Shah, A.D., Kim, J.-H., Huang, C.-H., 2011. Tertiary amines enhance reactions of organic contaminants with aqueous chlorine. Water research 45 (18), 6087-96. 
Soufan, M., Deborde, M., Legube, B., 2012. Aqueous chlorination of diclofenac: Kinetic study and transformation products identification. Water research 46.

Ternes, T., Bonerz, M., Schmidt, T., 2001. Determination of neutral pharmaceuticals in wastewater and rivers by liquid chromatography-electrospray tandem mass spectrometry. Journal of Chromatography A 938 (1), 175-185.

Vanková, M., others, 2010. Biodegradability analysis of pharmaceuticals used in developing countries; screening with OxiTop C-110.

De Wet, J.R., Wood, K., DeLuca, M., Helinski, D.R., Subramani, S., 1987. Firefly luciferase gene: structure and expression in mammalian cells. Molecular and cellular biology 7 (2), 725-737.

WHO, 2013. Global update on HIV treatment 2013: results, impact and opportunities.

Wood, T.P., Duvenage, C.S., Rohwer, E., 2015. The occurrence of anti-retroviral compounds used for HIV treatment in South African surface water. Environmental Pollution 199, 235-243.

Zhai, H., Zhang, X., Zhu, X., Liu, J., Ji, M., 2014. Formation of brominated disinfection byproducts during chloramination of drinking water: New polar species and overall kinetics. Environmental science $\ \&$ technology 48 (5), 2579-2588.

Zimmermann, S.G., Wittenwiler, M., Hollender, J., Krauss, M., Ort, C., Siegrist, H., von Gunten, U., 2011. Kinetic assessment and modeling of an ozonation step for full-scale municipal wastewater treatment: Micropollutant oxidation, by-product formation and disinfection. Water research 45 (2), 605-617. 


\section{Supplementary Information}

\section{List of Figures:}

Figure S1: The pseudomolecular ion $(\mathrm{m} / \mathrm{z} 267)$ peak area of Nevirapine $(37 \mu \mathrm{M})$ reacted with varying $\mathrm{NaOCl}$ over time at $\mathrm{pH} 5.8$ or $\mathrm{pH} 8$ in $10 \mathrm{mM}$ phosphate buffer or un-buffered, analysed by LC-QqQ.

Figure S2: Overlaid LC-UV trace $(254 \mathrm{~nm})$ of Nevirapine reacted with $100 \mu \mathrm{M} \mathrm{NaOCl}$ at $\mathrm{pH} 8$ (blue trace) and pH 5.8 (red trace) in $10 \mathrm{mM}$ phosphate buffer after 24 hours.

Figure S3: $\operatorname{Ln}(\mathrm{Ct} / \mathrm{C} 0)$ over time for kinetic measurements of Nevirapine $(2 \mu \mathrm{M})$ degradation at $\mathrm{pH} 5.8$ or 8 when chlorine is at a 10 fold excess $(20 \mu \mathrm{M})$.

Figure S4: The peak area of the extracted Nevirapine ion analysed by UHPLC-QTOF (top) and the average antiviral activity (bottom) of each of the chlorination reaction preparative chromatography fractions.

\section{List of Tables:}

Table S1: The most abundant unique entities identified from the Nevirapine chlorination reactions with proposed formulae, accurate mass, retention time (RT) and MS/MS fragment ions collated into a searcheable database with Agilent PCDL Manager.

Table S2: GPS co-ordinates of sampling areas.

Table S3: Nevirapine and its chlorination products detected by positive ESI UHPLC-QTOF analysis of SPE extracts of South African surface water samples.

Table S4: The in vitro viral activity of the fractions of the basic Nevirapine chlorination reaction. A value of $100 \%$ or more indicates that a fraction has no antiviral properties. $I C_{50}$ values were calculated from the average viral activity measured after exposure to each fraction at $10 \mu \mathrm{g} / \mathrm{mL}$.

Table S5: The in vitro viral activity of the fractions of the acidic Nevirapine chlorination reaction. A value of $100 \%$ or more indicates that a fraction has no antiviral properties. $I C_{50}$ values were calculated from the average viral activity measured after exposure to each fraction at $10 \mu \mathrm{g} / \mathrm{mL}$. 

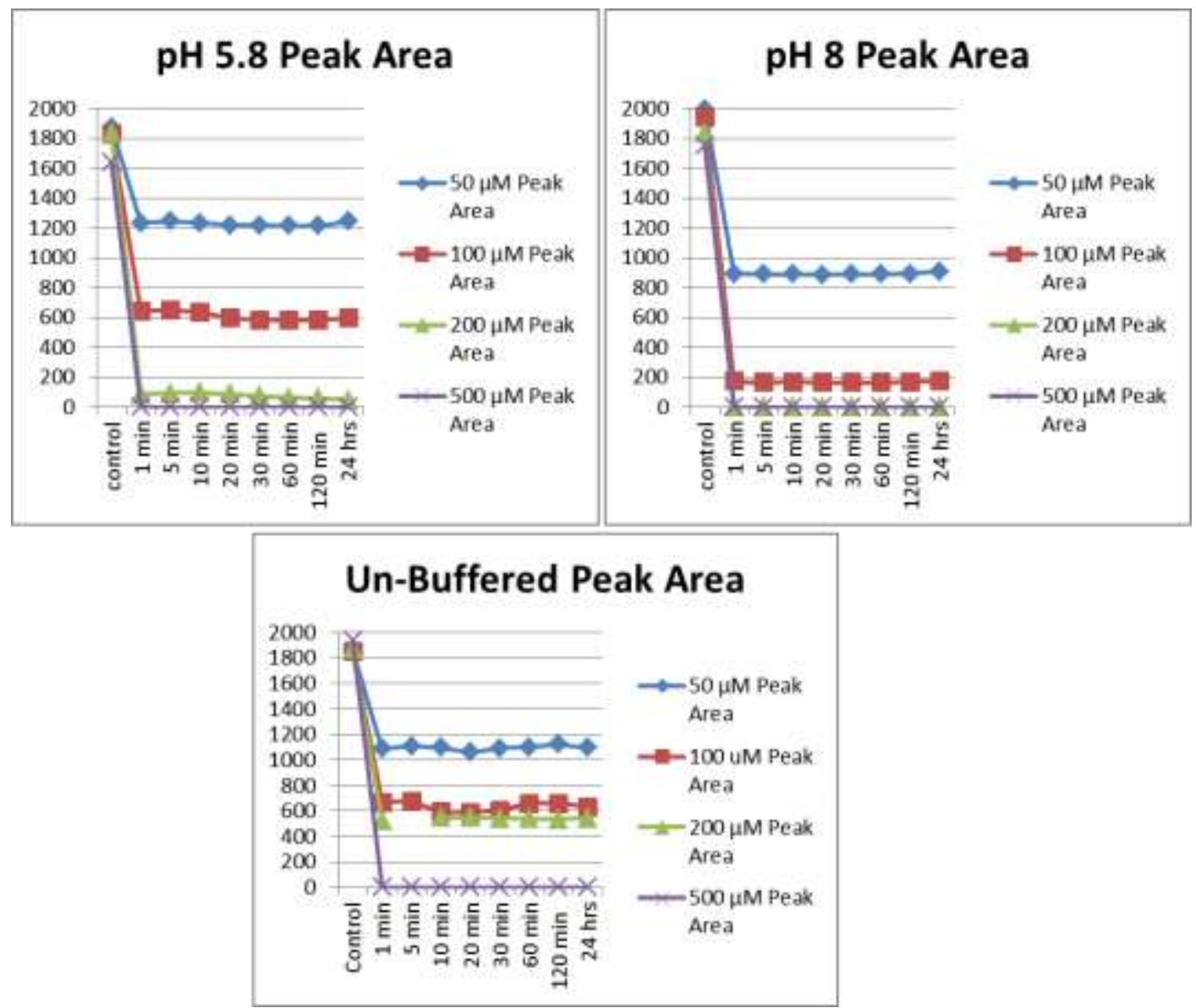

Figure S2: The pseudomolecular ion $(\mathrm{m} / \mathrm{z} 267)$ peak area of Nevirapine $(37 \mu \mathrm{M})$ reacted with varying $\mathrm{NaOCI}$ over time at pH 5.8 or pH 8 in $10 \mathrm{mM}$ phosphate buffer or un-buffered, analysed by LC-QqQ. 


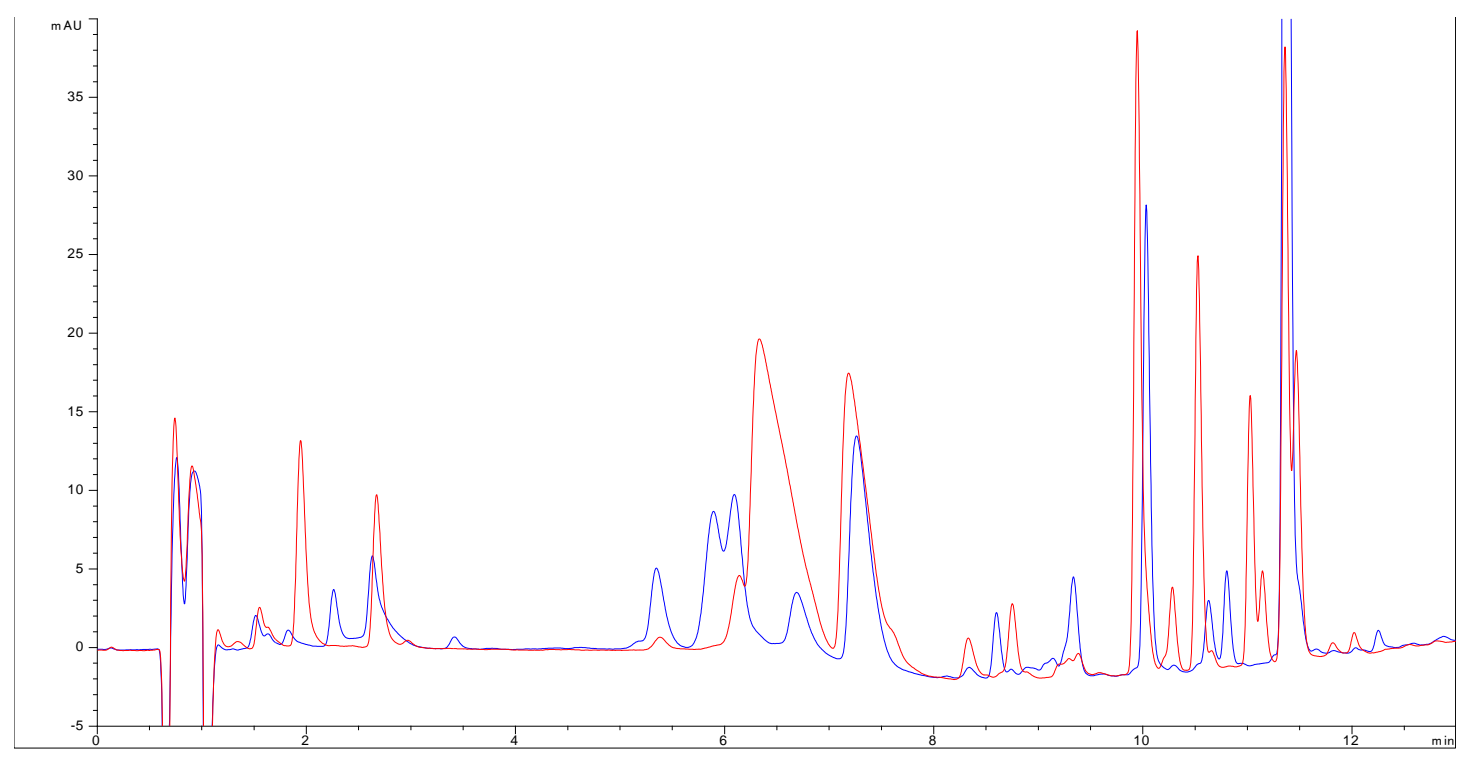

Figure S3: Overlaid LC-UV trace $(254 \mathrm{~nm})$ of Nevirapine reacted with $100 \mu \mathrm{M} \mathrm{NaOCl}$ at pH 8 (blue trace) and pH 5.8 (red trace) in $10 \mathrm{mM}$ phosphate buffer after 24 hours.

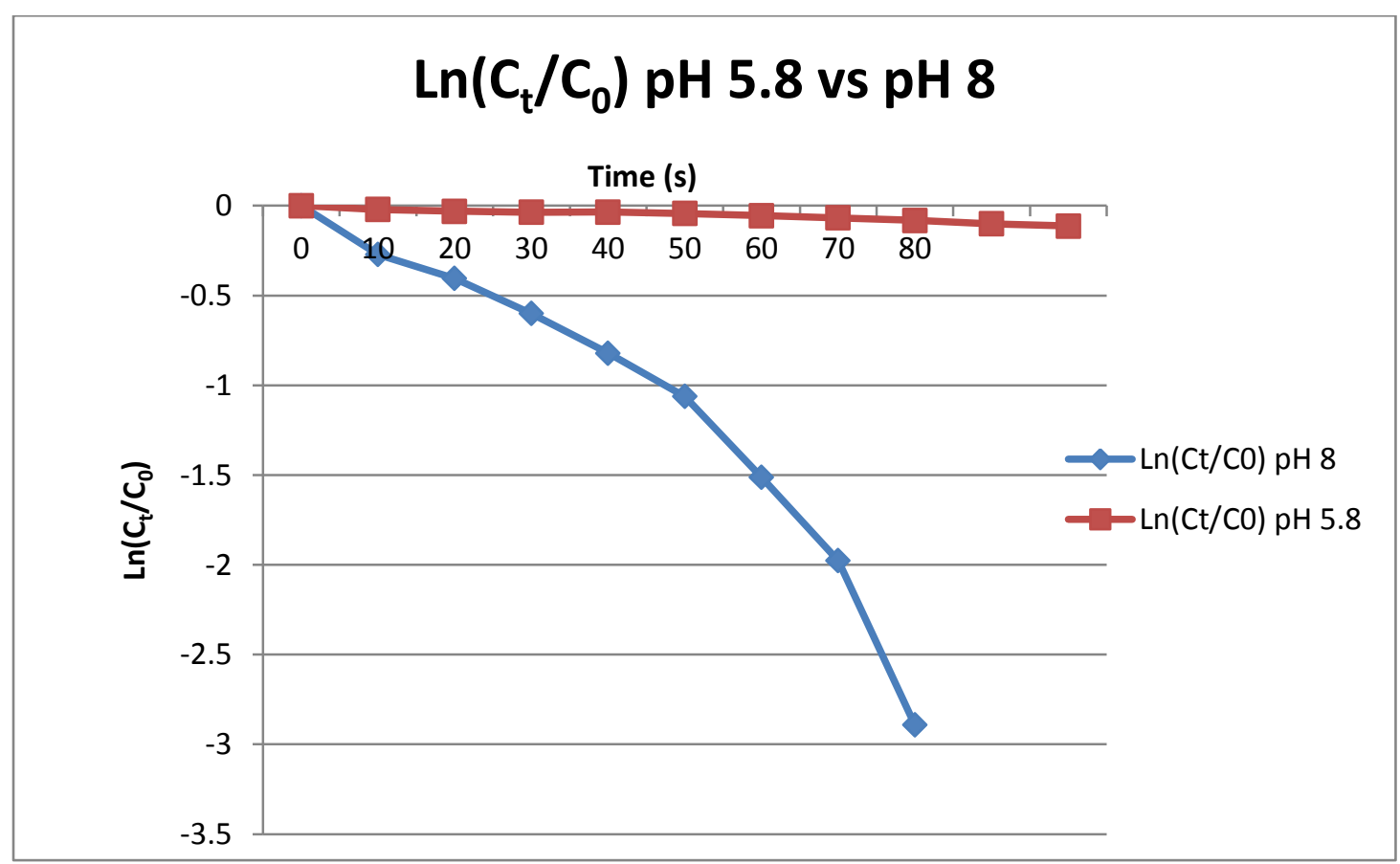

Figure S4: $\operatorname{Ln}(\mathrm{Ct} / \mathrm{C} 0)$ over time for kinetic measurements of Nevirapine $(2 \mu \mathrm{M})$ degradation at pH 5.8 or 8 when chlorine is at a 10 fold excess $(20 \mu \mathrm{M})$. 
Table S6: The most abundant unique entities identified from the Nevirapine chlorination reactions with proposed formulae, accurate mass, retention time (RT) and MS/MS fragment ions collated into a searcheable database with Agilent PCDL Manager.

\begin{tabular}{|c|c|c|c|c|}
\hline $\begin{array}{l}\text { Compound } \\
\text { Name }\end{array}$ & $\begin{array}{l}\text { Proposed } \\
\text { Formula* }^{*}\end{array}$ & $\begin{array}{l}\text { Measured } \\
\text { Mass }\end{array}$ & RT (min) & MS/MS Fragment Ions \\
\hline 1 & - & 121.9176 & 0.442 & \\
\hline 2 & $\mathrm{C}_{9} \mathrm{H}_{9} \mathrm{~N}_{3}$ & 159.0787 & 3.216 & $120.0547,97.9662,56.9407$ \\
\hline 3 & $\mathrm{C}_{9} \mathrm{H}_{8} \mathrm{~N}_{2} \mathrm{O}$ & 160.0665 & 0.663 & 133.0762, 78.0338, 118.0638, 121.0403 \\
\hline 4 & $\mathrm{C}_{9} \mathrm{H}_{9} \mathrm{~N}_{3} \mathrm{O}$ & 175.0753 & 5.331 & $\begin{array}{l}\text { 136.0503, 135.0425, 148.0509, 116.9766, } \\
120.0565\end{array}$ \\
\hline 5 & $\mathrm{C}_{9} \mathrm{H}_{10} \mathrm{~N}_{2} \mathrm{O}_{2}$ & 178.0742 & 1.211 & $136.9316,118.9201,56.9641$ \\
\hline 6 & $\mathrm{C}_{10} \mathrm{H}_{9} \mathrm{~N}_{3} \mathrm{O}$ & 187.0751 & 4.723 & $148.0505,171.0556,133.0751,93.0435$ \\
\hline 7 & $\mathrm{C}_{11} \mathrm{H}_{8} \mathrm{~N}_{2} \mathrm{O}_{2}$ & 200.0593 & 5.588 & $80.0491,122.023,183.0555$ \\
\hline 8 & $\mathrm{C}_{11} \mathrm{H}_{8} \mathrm{~N}_{2} \mathrm{O}_{2}$ & 200.0596 & 6.304 & $122.0236,183.0550,186.0431,173.0721$ \\
\hline 9 & $\mathrm{C}_{10} \mathrm{H}_{10} \mathrm{~N}_{4} \mathrm{O}$ & 202.0851 & 2.295 & $163.0616,186.0664,161.0711,121.0391$ \\
\hline 10 & $\mathrm{C}_{10} \mathrm{H}_{9} \mathrm{~N}_{3} \mathrm{O}_{2}$ & 203.0704 & 5.698 & $\begin{array}{l}\text { 161.0708, 204.0760, 133.0755, 78.0330, } \\
118.06490\end{array}$ \\
\hline 11 & - & 205.8791 & 0.442 & - \\
\hline 12 & - & 207.8773 & 0.44 & - \\
\hline 13 & - & 211.8456 & 0.468 & בn \\
\hline 14 & $\mathrm{C}_{10} \mathrm{H}_{10} \mathrm{~N}_{4} \mathrm{O}_{2}$ & 218.0828 & 0.631 & $161.0468,219.0881,201.0775$ \\
\hline Nevirapine & $\mathrm{C}_{15} \mathrm{H}_{14} \mathrm{~N}_{4} \mathrm{O}$ & 266.1168 & 7.178 & $226.0858,107.0605,161.0712,198.0906$ \\
\hline 15 & $\mathrm{C}_{14} \mathrm{H}_{13} \mathrm{~N}_{3} \mathrm{O}_{3}$ & 271.0964 & 6.226 & $\begin{array}{l}\text { 254.0923, 214.0608, 161.0707, 272.1019, } \\
186.0657\end{array}$ \\
\hline 16 & $\mathrm{C}_{14} \mathrm{H}_{13} \mathrm{~N}_{3} \mathrm{O}_{3}$ & 271.0965 & 6.351 & $\begin{array}{l}\text { 254.0929, 214.0610, 161.0708, 186.0656, } \\
272.1019,133.0763,118.0654\end{array}$ \\
\hline 17 & $\mathrm{C}_{15} \mathrm{H}_{14} \mathrm{~N}_{4} \mathrm{O}_{2}$ & 282.1117 & 5.409 & (2) \\
\hline 18 & $\mathrm{C}_{15} \mathrm{H}_{14} \mathrm{~N}_{4} \mathrm{O}_{2}$ & 282.1117 & 6.206 & $161.0710,242.0793,214.0845,123.05520$ \\
\hline 19 & $\mathrm{C}_{15} \mathrm{H}_{14} \mathrm{~N}_{4} \mathrm{O}_{2}$ & 282.1118 & 6.853 & $\begin{array}{l}\text { 255.1243, 243.0877, 242.0798, 213.0777, } \\
215.0938,161.0701\end{array}$ \\
\hline 20 & $\mathrm{C}_{16} \mathrm{H}_{16} \mathrm{~N}_{4} \mathrm{O}_{2}$ & 296.1278 & 9.642 & $\begin{array}{l}282.1106,297.1339,267.0869,137.0705, \\
256.0960\end{array}$ \\
\hline 21 & $\mathrm{C}^{15} \mathrm{H}_{13} \mathrm{~N}_{3} \mathrm{O}_{4}$ & 299.0911 & 6.498 & $\begin{array}{l}\text { 122.0233, 96.0439, 217.0618, 187.0499, } \\
189.0659\end{array}$ \\
\hline 22 & $\mathrm{C}_{15} \mathrm{H}_{16} \mathrm{~N}_{4} \mathrm{O}_{3}$ & 300.1222 & 5.37 & $161.0712,133.0764,78.0338,106.0303$ \\
\hline 23 & $\mathrm{C}_{15} \mathrm{H}_{15} \mathrm{~N}_{3} \mathrm{O}_{4}$ & 301.1058 & 5.588 & $122.0235,94.0280,98.0601,96.0446$ \\
\hline 24 & $\mathrm{C}_{1} 5 \mathrm{H}_{15} \mathrm{~N}_{3} \mathrm{O}_{4}$ & 301.1061 & 6.303 & - \\
\hline 25 & $\mathrm{C}_{15} \mathrm{H}_{15} \mathrm{~N}_{3} \mathrm{O}_{4}$ & 301.1061 & 6.305 & (1) \\
\hline 26 & - & 309.8221 & 0.523 & $212.8518,174.8963,94.9287$ \\
\hline 27 & $\mathrm{C}_{15} \mathrm{H}_{14} \mathrm{~N}_{4} \mathrm{O}_{4}$ & 314.1014 & 6.033 & $\begin{array}{l}269.1039,315.1080,297.0994,241.1089, \\
203.0943\end{array}$ \\
\hline 28 & $\mathrm{C}_{15} \mathrm{H}_{14} \mathrm{~N}_{4} \mathrm{O}_{4}$ & 314.1018 & 5.099 & $\begin{array}{l}\text { 161.0710, 133.0756, 118.0660, 78.0326, } \\
105.0456\end{array}$ \\
\hline 29 & $\mathrm{C}_{15} \mathrm{H}_{14} \mathrm{~N}_{4} \mathrm{O}_{4}$ & 314.102 & 6.43 & $\begin{array}{l}\text { 269.1038, 315.1081, 229.0721, 297.0972, } \\
241.1080,242.0794\end{array}$ \\
\hline 30 & $\mathrm{C}_{15} \mathrm{H}_{13} \mathrm{CIN}_{4} \mathrm{O}_{2}$ & 316.0731 & 7.251 & $\begin{array}{l}161.0708,276.0408,158.0240,248.0462, \\
157.0166\end{array}$ \\
\hline 31 & $\mathrm{C}_{15} \mathrm{H}_{15} \mathrm{~N}_{3} \mathrm{O}_{5}$ & 317.1013 & 6.498 & 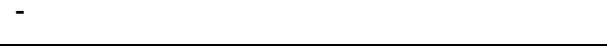 \\
\hline 32 & $\mathrm{C}_{19} \mathrm{H}_{12} \mathrm{O}_{5}$ & 320.0676 & 6.853 & $208.0979,252.3384,321.1343,92.9652$ \\
\hline
\end{tabular}




\begin{tabular}{|r|l|r|r|l|}
\hline 33 & $\mathrm{C}_{16} \mathrm{H}_{17} \mathrm{~N}_{3} \mathrm{O}_{5}$ & 331.1167 & 7.565 & - \\
\hline 34 & $\mathrm{C}_{16} \mathrm{H}_{12} \mathrm{~N}_{8} \mathrm{O}$ & 332.1136 & 1.501 & $227.0923,333.1186,287.1137,245.1028$, \\
\hline 35 & - & 347.7782 & 0.49 & - \\
\hline 36 & $\mathrm{C}_{21} \mathrm{H}_{14} \mathrm{O}_{6}$ & 362.0781 & 5.47 & $283.1199,345.0749,161.0715,242.0800$ \\
\hline 37 & $\mathrm{C}_{21} \mathrm{H}_{14} \mathrm{O}_{6}$ & 362.0785 & 5.409 & - \\
\hline 38 & $\mathrm{C}_{21} \mathrm{H}_{14} \mathrm{O}_{7}$ & 378.0731 & 5.134 & $243.0877,188.0815,161.0699,379.0804$, \\
\hline 39 & - & 379.7677 & 0.452 & - \\
\hline 40 & - & 379.7678 & 0.454 & - \\
\hline 41 & $\mathrm{C}_{18} \mathrm{H}_{12} \mathrm{~N}_{2} \mathrm{O}_{8}$ & 384.0605 & 5.419 & $283.1188,305.0983,161.0695,265.1084$ \\
\hline 42 & - & 483.7118 & 0.504 & - \\
\hline
\end{tabular}

* - denotes an entity for which a formula could not be proposed with greater than $90 \%$ certainty and/or cases for which automatic MS/MS did not record spectra for a particular compound.

Table S7: GPS co-ordinates of sampling areas.

\begin{tabular}{|l|l|}
\hline Sample Name & GPS Co-Ordinates \\
\hline Roodeplaat Dam System ${ }^{*}$ & $-25.678677,28.357116$ \\
\hline Pienaars River Inflow & $-25.624620,28.341890$ \\
\hline Zeekoegat WWTW Outflow & $-25.626404,28.345692$ \\
\hline Angling Area & $-25.637763,28.344150$ \\
\hline S.E Bank & $-25.618238,28.358642$ \\
\hline Motorboat Launch & $-25.623345,28.349842$ \\
\hline Rowing Club & $-25.608244,28.367231$ \\
\hline Roodeplaat Outflow & $-25.881576,28.268585$ \\
\hline Rietvlei Dam ${ }^{*}$ & $-25.876767,28.279846$ \\
\hline Southern Bank & $-29.070882,23.637209$ \\
\hline Northern Bank & $-29.072898,23.638936$ \\
\hline Orange River System & $-30.534671810,23.635868$ \\
\hline Orange River (Bethulie) & $-30.603858,25.503609$ \\
\hline Gariep Dam Oviston & \\
\hline Gariep Dam (N.E) & \\
\hline Vaal confluence & \\
\hline Orange confluence & \\
\hline Confluence & \\
\hline
\end{tabular}




\begin{tabular}{|c|c|}
\hline \multicolumn{2}{|l|}{ Cape Region } \\
\hline Eerste Rivier* & $-33.941603,18.857078$ \\
\hline Theewaterskloof Dam & $-34.027283,19.208261$ \\
\hline \multicolumn{2}{|l|}{ Vaal Dam } \\
\hline Dam wall & $-26.883278,28.116047$ \\
\hline Oranjeville & $-26.999155,28.214893$ \\
\hline Vaal Dam Inflow & $-27.020575,28.608589$ \\
\hline Vaal Dam Out Flow & $-26.874950,28.115583$ \\
\hline \multicolumn{2}{|l|}{ Single system samples } \\
\hline Hartebeesfontein WWTW Outflow* & $-26.030715,28.291084$ \\
\hline Ditholo & $-25.320242,28.340728$ \\
\hline Hartbeespoort Dam, Meerhof $(2011)^{*}$ & $-25.760775,27.891871$ \\
\hline Hartbeespoort Dam, Meerhof $(2014)^{\star}$ & $-25.760775,27.891871$ \\
\hline Hartbeespoort Dam, Tap Water Sample* & $-25.745594,27.911238$ \\
\hline Hartbeespoort Inflow, Crocodile River & $-25.775818,27.901601$ \\
\hline Renosterkop & $-25.108639,28.887359$ \\
\hline Inanda Dam & $-29.673792,30.854874$ \\
\hline Inanda Dam offshore & $-29.674016,30.860239$ \\
\hline
\end{tabular}

* Indicates that the sample was taken in or near an urban environment. 
Table S8: Nevirapine and its chlorination products detected by positive ESI UHPLC-QTOF analysis of SPE extracts of South African surface water samples.

\begin{tabular}{|c|c|c|c|c|c|c|c|c|}
\hline GPS & Description & $\mathrm{m} / \mathbf{z}$ & $\mathbf{R T}^{*}$ & RT Diff (DB) $)^{\star *}$ & Diff $(\mathrm{DB}, \mathrm{mDa})^{\star \star}$ & Mass & Peak Height & Proposed Formula \\
\hline \multicolumn{9}{|l|}{ Roodeplaat Dam System } \\
\hline$-25.678677,28.357116$ & Pienaars River before Roodeplaat Dam & 170.0722 & 4.792 & -0.069 & -0.32 & 187.0754 & 51552 & $\mathrm{C}_{10} \mathrm{H}_{9} \mathrm{~N}_{3} \mathrm{O}$ \\
\hline$-25.678677,28.357116$ & Pienaars River before Roodeplaat Dam & 188.0824 & 4.685 & 0.038 & -0.16 & 187.0753 & 582284 & $\mathrm{C}_{10} \mathrm{H}_{9} \mathrm{~N}_{3} \mathrm{O}$ \\
\hline$-25.678677,28.357116$ & Pienaars River before Roodeplaat Dam & 267.1248 & 7.142 & 0.036 & -0.76 & 266.1175 & 3247866 & $\mathrm{C}_{15} \mathrm{H}_{14} \mathrm{~N}_{4} \mathrm{O}$ (Nevirapine) \\
\hline$-25.678677,28.357116$ & Pienaars River before Roodeplaat Dam & 283.1192 & 6.159 & 0.047 & -0.37 & 282.1121 & 1473596 & $\mathrm{C}_{15} \mathrm{H}_{14} \mathrm{~N}_{4} \mathrm{O}_{2}$ \\
\hline$-25.678677,28.357116$ & Pienaars River before Roodeplaat Dam & 317.0807 & 7.231 & 0.02 & -0.67 & 316.0738 & 57884 & $\mathrm{C}_{15} \mathrm{H}_{13} \mathrm{Cl} \mathrm{N} \mathrm{O}_{2}$ \\
\hline$-25.626404,28.345692$ & Roodeplaat Angling Area & 267.1243 & 7.132 & 0.046 & -0.22 & 266.117 & 1200003 & $\mathrm{C}_{15} \mathrm{H}_{14} \mathrm{~N}_{4} \mathrm{O}$ (Nevirapine) \\
\hline$-25.626404,28.345692$ & Roodeplaat Angling Area & 188.0824 & 4.683 & 0.04 & -0.23 & 187.0753 & 95604 & $\mathrm{C}_{10} \mathrm{H}_{9} \mathrm{~N}_{3} \mathrm{O}$ \\
\hline$-25.626404,28.345692$ & Roodeplaat Angling Area & 375.1588 & 4.828 & -0.105 & -2.38 & 187.0775 & 81153 & $\mathrm{C}_{10} \mathrm{H}_{9} \mathrm{~N}_{3} \mathrm{O}$ \\
\hline$-25.624620,28.341890$ & Zeekoegat WWTW Outflow & 188.0823 & 4.655 & 0.068 & 0.01 & 187.0751 & 321806 & $\mathrm{C}_{10} \mathrm{H}_{9} \mathrm{~N}_{3} \mathrm{O}$ \\
\hline$-25.637763,28.344150$ & Roodeplaat S.E. Bank & 188.0829 & 4.626 & 0.097 & -0.74 & 187.0758 & 99686 & $\mathrm{C}_{10} \mathrm{H}_{9} \mathrm{~N}_{3} \mathrm{O}$ \\
\hline$-25.637763,28.344150$ & Roodeplaat S.E. Bank & 267.1252 & 7.153 & 0.025 & -0.39 & 266.1172 & 1668882 & $\mathrm{C}_{15} \mathrm{H}_{14} \mathrm{~N}_{4} \mathrm{O}$ (Nevirapine) \\
\hline$-25.618238,28.358642$ & Roodeplaat Motor Boat Launch & 188.0824 & 4.662 & 0.061 & -0.22 & 187.0753 & 126361 & $\mathrm{C}_{10} \mathrm{H}_{9} \mathrm{~N}_{3} \mathrm{O}$ \\
\hline$-25.618238,28.358643$ & Roodeplaat Motor Boat Launch & 267.1251 & 7.16 & 0.018 & -1.16 & 266.1179 & 1742427 & $\mathrm{C}_{15} \mathrm{H}_{14} \mathrm{~N}_{4} \mathrm{O}$ (Nevirapine) \\
\hline$-25.623345,28.349842$ & Roodeplaat Rowing Club & 188.0825 & 4.652 & 0.071 & -0.33 & 187.0754 & 125822 & $\mathrm{C}_{10} \mathrm{H}_{9} \mathrm{~N}_{3} \mathrm{O}$ \\
\hline$-25.608244,28.367231$ & Roodeplaat Dam Outflow & 267.125 & 7.15 & 0.028 & -1.03 & 266.1178 & 1492262 & $\mathrm{C}_{15} \mathrm{H}_{14} \mathrm{~N}_{4} \mathrm{O}$ (Nevirapine) \\
\hline \multicolumn{9}{|l|}{ Orange-Vaal System } \\
\hline$-30.534670,26.022975$ & Orange River (Bethuli) & 267.1236 & 7.133 & 0.045 & 0.33 & 266.1164 & 21351 & $\mathrm{C}_{15} \mathrm{H}_{14} \mathrm{~N}_{4} \mathrm{O}$ (Nevirapine) \\
\hline$-29.071810,23.635868$ & Orange-Vaal River Confluence & 267.124 & 7.133 & 0.045 & -0.07 & 266.1168 & 46847 & $\mathrm{C}_{15} \mathrm{H}_{14} \mathrm{~N}_{4} \mathrm{O}$ (Nevirapine) \\
\hline$-29.070882,23.637209$ & Vaal River Confluence & 267.1242 & 7.133 & 0.045 & -0.24 & 266.117 & 44894 & $\mathrm{C}_{15} \mathrm{H}_{14} \mathrm{~N}_{4} \mathrm{O}$ (Nevirapine) \\
\hline$-30.603858,25.503609$ & Gariep Dam N.E Bank & 267.1241 & 7.137 & 0.041 & -0.06 & 266.1168 & 50227 & $\mathrm{C}_{15} \mathrm{H}_{14} \mathrm{~N}_{4} \mathrm{O}$ (Nevirapine) \\
\hline$-26.999155,28.214893$ & Oranjeville Bridge & 283.1197 & 6.399 & -0.193 & -1.15 & 282.1128 & 47585 & $\mathrm{C}_{15} \mathrm{H}_{14} \mathrm{~N}_{4} \mathrm{O}_{2}$ \\
\hline$-26.874950,28.115583$ & Vaal Dam Outflow & 267.1253 & 7.14 & 0.038 & -1.25 & 266.118 & 305071 & $\mathrm{C}_{15} \mathrm{H}_{14} \mathrm{~N}_{4} \mathrm{O}$ (Nevirapine) \\
\hline \multicolumn{9}{|c|}{ Hartbeespoort/Crocodile River System } \\
\hline$-25.760775,27.891871$ & Hartbeespoort Dam, Meerhof & 267.1251 & 7.134 & 0.044 & -1.24 & 266.118 & 790461 & $\mathrm{C}_{15} \mathrm{H}_{14} \mathrm{~N}_{4} \mathrm{O}$ (Nevirapine) \\
\hline$-25.775818,27.901601$ & Hartbeespoort Inflow, Crocodile River & 267.1251 & 7.087 & 0.091 & -1.13 & 266.1179 & 429248 & $\mathrm{C}_{15} \mathrm{H}_{14} \mathrm{~N}_{4} \mathrm{O}$ (Nevirapine) \\
\hline$-25.775818,27.901601$ & Hartbeespoort Inflow, Crocodile River & 283.1196 & 6.398 & -0.192 & -0.98 & 282.1127 & 560137 & $\mathrm{C}_{15} \mathrm{H}_{14} \mathrm{~N}_{4} \mathrm{O}_{2}$ \\
\hline
\end{tabular}




\begin{tabular}{|c|c|c|c|c|c|c|c|c|}
\hline$-25.775818,27.901601$ & Hartbeespoort Inflow, Crocodile River & 188.0822 & 4.613 & 0.11 & -0.02 & 187.0751 & 81918 & $\mathrm{C}_{10} \mathrm{H}_{9} \mathrm{~N}_{3} \mathrm{O}$ \\
\hline \multicolumn{9}{|l|}{ Single Samples } \\
\hline$-26.030715,28.291084$ & Hartbeesfontein WWTW & 267.124 & 7.139 & 0.039 & -0.08 & 266.1168 & 799749 & $\mathrm{C}_{15} \mathrm{H}_{14} \mathrm{~N}_{4} \mathrm{O}$ (Nevirapine) \\
\hline$-26.030715,28.291084$ & Hartbeesfontein WWTW & 283.1187 & 6.901 & -0.048 & -0.35 & 282.1122 & 36425 & $\mathrm{C}_{15} \mathrm{H}_{14} \mathrm{~N}_{4} \mathrm{O}_{2}$ \\
\hline$-26.030715,28.291084$ & Hartbeesfontein WWTW & 158.0723 & 5.175 & 0.156 & 0.03 & 175.0753 & 2041054 & $\mathrm{C}_{9} \mathrm{H}_{9} \mathrm{~N}_{3} \mathrm{O}$ \\
\hline$-25.881576,28.268585$ & Rietvlei Dam & 267.1248 & 7.128 & 0.05 & -0.77 & 266.1175 & 744658 & $\mathrm{C}_{15} \mathrm{H}_{14} \mathrm{~N}_{4} \mathrm{O}$ (Nevirapine) \\
\hline$-25.881576,28.268585$ & Rietvlei Dam & 158.0715 & 5.166 & 0.165 & 0.75 & 175.0745 & 1145107 & $\mathrm{C}_{9} \mathrm{H}_{9} \mathrm{~N}_{3} \mathrm{O}$ \\
\hline$-29.673792,30.854874$ & Inanda Dam Bank & 267.1233 & 7.14 & 0.038 & 0.59 & 266.1162 & 247851 & $\mathrm{C}_{15} \mathrm{H}_{14} \mathrm{~N}_{4} \mathrm{O}$ \\
\hline$-29.674016,30.860239$ & Inanda Dam Centre & 267.1233 & 7.125 & 0.053 & 0.65 & 266.1161 & 319778 & $\mathrm{C}_{15} \mathrm{H}_{14} \mathrm{~N}_{4} \mathrm{O}$ \\
\hline
\end{tabular}


Table S9: The in vitro viral activity of the fractions of the basic Nevirapine chlorination reaction. A value of $100 \%$ or more indicates that a fraction has no antiviral properties. The concentration at which $50 \%$ of the virus is inhibited $\left(\mathrm{IC}_{50}\right)$ was calculated from the average viral activity measured after exposure to each fraction at $10 \mu \mathrm{g} / \mathrm{mL}$.

\begin{tabular}{|c|c|c|c|c|c|}
\hline \multirow[b]{2}{*}{ NVP Basic Fractions: } & \multicolumn{4}{|c|}{ Percent virus activity } & \multirow[b]{2}{*}{$\begin{array}{c}\text { Calculated IC } \\
(\mu \mathrm{g} / \mathrm{mL})^{\star}\end{array}$} \\
\hline & 1 & 2 & Average & Standev & \\
\hline Nev. Rxn. FC C1 & $103.6 \%$ & $102.4 \%$ & $103.0 \%$ & $0.8 \%$ & - \\
\hline Nev. Rxn. FC C2 & $97.7 \%$ & $98.4 \%$ & $98.1 \%$ & $0.5 \%$ & 19.6 \\
\hline Nev. Rxn. FC C3 & $60.8 \%$ & $61.4 \%$ & $61.1 \%$ & $0.5 \%$ & 12.2 \\
\hline Nev. Rxn. FC C4 & $4.7 \%$ & $3.9 \%$ & $4.3 \%$ & $0.6 \%$ & 0.9 \\
\hline Nev. Rxn. FC C5 & $4.9 \%$ & $4.3 \%$ & $4.6 \%$ & $0.4 \%$ & 0.9 \\
\hline Nev. Rxn. FC C6 & $8.7 \%$ & $7.7 \%$ & $8.2 \%$ & $0.7 \%$ & 1.6 \\
\hline Nev. Rxn. FC C7 & $14.0 \%$ & $12.4 \%$ & $13.2 \%$ & $1.1 \%$ & 2.6 \\
\hline Nev. Rxn. FC C8 & $18.4 \%$ & $16.6 \%$ & $17.5 \%$ & $1.2 \%$ & 3.5 \\
\hline Nev. Rxn. FC C9 & $8.5 \%$ & $8.1 \%$ & $8.3 \%$ & $0.3 \%$ & 1.7 \\
\hline Nev. Rxn. FC C10 & $26.2 \%$ & $26.0 \%$ & $26.1 \%$ & $0.2 \%$ & 5.2 \\
\hline Nev. Rxn. FC C11 & $29.4 \%$ & $29.8 \%$ & $29.6 \%$ & $0.2 \%$ & 5.9 \\
\hline Nev. Rxn. FC C12 & $36.6 \%$ & $37.7 \%$ & $37.1 \%$ & $0.8 \%$ & 7.4 \\
\hline Nev. Rxn. FC C13 & $12.4 \%$ & $11.6 \%$ & $12.0 \%$ & $0.6 \%$ & 2.4 \\
\hline Nev. Rxn. FC C14 & $2.5 \%$ & $1.7 \%$ & $2.1 \%$ & $0.6 \%$ & 0.4 \\
\hline Nev. Rxn. FC C15 & $4.5 \%$ & $4.4 \%$ & $4.4 \%$ & $0.0 \%$ & 0.9 \\
\hline Nev. Rxn. FC C16 & $21.1 \%$ & $17.9 \%$ & $19.5 \%$ & $2.2 \%$ & 3.9 \\
\hline Nev. Rxn. FC C17 & $38.5 \%$ & $36.0 \%$ & $37.2 \%$ & $1.7 \%$ & 7.4 \\
\hline Nev. Rxn. FC C18 & $45.6 \%$ & $42.7 \%$ & $44.2 \%$ & $2.1 \%$ & 8.8 \\
\hline Nev. Rxn. FC C19 & $42.7 \%$ & $39.0 \%$ & $40.9 \%$ & $2.6 \%$ & 8.2 \\
\hline Nev. Rxn. FC C20 & $29.2 \%$ & $26.1 \%$ & $27.7 \%$ & $2.2 \%$ & 5.5 \\
\hline Nev. Rxn. FC C21 & $29.8 \%$ & $29.9 \%$ & $29.9 \%$ & $0.1 \%$ & 6.0 \\
\hline Nev. Rxn. FC C22 & $50.8 \%$ & $52.0 \%$ & $51.4 \%$ & $0.9 \%$ & 10.3 \\
\hline Nev. Rxn. FC C23 & $59.1 \%$ & $58.7 \%$ & $58.9 \%$ & $0.3 \%$ & 11.8 \\
\hline Nev. Rxn. FC C24 & $50.7 \%$ & $53.1 \%$ & $51.9 \%$ & $1.7 \%$ & 10.4 \\
\hline Nev. Rxn. FC C25 & $71.2 \%$ & $73.9 \%$ & $72.5 \%$ & $1.9 \%$ & 14.5 \\
\hline Nev. Rxn. FC C26 & $89.6 \%$ & $88.9 \%$ & $89.3 \%$ & $0.5 \%$ & 17.9 \\
\hline
\end{tabular}




\begin{tabular}{|c|c|c|c|c|c|}
\hline Nev. Rxn. FC C27 & $89.1 \%$ & $94.7 \%$ & $91.9 \%$ & $4.0 \%$ & 18.4 \\
\hline Nev. Rxn. FC C30 & $83.4 \%$ & $92.9 \%$ & $88.1 \%$ & $6.7 \%$ & 17.6 \\
\hline Nev. Rxn. FC C31 & $89.6 \%$ & $92.2 \%$ & $90.9 \%$ & $1.9 \%$ & 18.2 \\
\hline Nev. Rxn. FC C32 & $91.4 \%$ & $94.2 \%$ & $92.8 \%$ & $2.0 \%$ & 18.6 \\
\hline Nev. Rxn. FC C33 & $100.6 \%$ & $101.1 \%$ & $100.9 \%$ & $0.4 \%$ & - \\
\hline Nev. Rxn. FC C34 & $92.2 \%$ & $93.4 \%$ & $92.8 \%$ & $0.9 \%$ & 18.6 \\
\hline Nev. Rxn. FC C35 & $94.9 \%$ & $99.5 \%$ & $97.2 \%$ & $3.2 \%$ & 19.4 \\
\hline Nev. Rxn. FC C36 & $91.3 \%$ & $98.2 \%$ & $94.7 \%$ & $4.9 \%$ & 18.9 \\
\hline Nev. Rxn. FC C37 & $94.3 \%$ & $94.1 \%$ & $94.2 \%$ & $0.1 \%$ & 18.8 \\
\hline Nev. Rxn. FC C38 & $95.5 \%$ & $95.1 \%$ & $95.3 \%$ & $0.2 \%$ & 19.1 \\
\hline Nev. Rxn. FC C39 & $101.4 \%$ & $95.6 \%$ & $98.5 \%$ & $4.1 \%$ & 19.7 \\
\hline Nev. Rxn. FC C40 & $90.2 \%$ & $91.6 \%$ & $90.9 \%$ & $1.0 \%$ & 18.2 \\
\hline Nev. Rxn. FC C41 & $94.4 \%$ & $96.6 \%$ & $95.5 \%$ & $1.6 \%$ & 19.1 \\
\hline Nev. Rxn. FC C42 & $95.8 \%$ & $100.1 \%$ & $97.9 \%$ & $3.0 \%$ & 19.6 \\
\hline Nev. Rxn. FC C50 & $95.2 \%$ & $88.6 \%$ & $91.9 \%$ & $4.7 \%$ & 18.4 \\
\hline Nev. Rxn. FC C51 & $99.1 \%$ & $89.7 \%$ & $94.4 \%$ & $6.7 \%$ & 18.9 \\
\hline Nev. Rxn. FC C52 & $99.5 \%$ & $88.1 \%$ & $93.8 \%$ & $8.0 \%$ & 18.8 \\
\hline Nev. Rxn. FC C53 & $92.4 \%$ & $88.6 \%$ & $90.5 \%$ & $2.7 \%$ & 18.1 \\
\hline Nev. Rxn. FC C54 & $114.8 \%$ & $113.4 \%$ & $114.1 \%$ & $1.0 \%$ & - \\
\hline
\end{tabular}

* The calculation is based on the assumption that the relationship between antiviral activity and test compound concentration is linear; - where viral activity is $\geq 100 \%$ at $10 \mu \mathrm{g} / \mathrm{mL}$, the $\mathrm{IC}_{50}$ could not be calculated. 
Table S10: The in vitro viral activity of the fractions of the acidic Nevirapine chlorination reaction. A value of $100 \%$ or more indicates that a fraction has no antiviral properties. The concentration at which $50 \%$ of the virus is inhibited $\left(\mathrm{IC}_{50}\right)$ was calculated from the average viral activity measured after exposure to each fraction at $10 \mu \mathrm{g} / \mathrm{mL}$.

\begin{tabular}{|c|c|c|c|c|c|}
\hline \multirow[b]{2}{*}{ NVP Acidic Fractions: } & \multicolumn{4}{|c|}{ Percent virus activity } & \multirow[b]{2}{*}{$\begin{array}{c}\text { Calculated } \\
\text { IC }_{50} \\
(\mu \mathrm{g} / \mathrm{mL})^{\star}\end{array}$} \\
\hline & 1 & 2 & Average & Standev & \\
\hline Nev. Acid Rxn. FC D1 & $87.5 \%$ & $84.7 \%$ & $86.1 \%$ & $1.9 \%$ & 17.2 \\
\hline Nev. Acid Rxn. FC D2 & $101.1 \%$ & $98.3 \%$ & $99.7 \%$ & $2.0 \%$ & 19.9 \\
\hline Nev. Acid Rxn. FC D3 & $102.9 \%$ & $105.6 \%$ & $104.2 \%$ & $1.9 \%$ & - \\
\hline Nev. Acid Rxn. FC D4 & $101.8 \%$ & $107.1 \%$ & $104.5 \%$ & $3.8 \%$ & - \\
\hline Nev. Acid Rxn. FC D5 & $100.8 \%$ & $97.5 \%$ & $99.1 \%$ & $2.4 \%$ & 19.8 \\
\hline Nev. Acid Rxn. FC D6 & $97.5 \%$ & $97.6 \%$ & $97.5 \%$ & $0.1 \%$ & 19.5 \\
\hline Nev. Acid Rxn. FC D7 & $96.3 \%$ & $96.8 \%$ & $96.5 \%$ & $0.4 \%$ & 19.3 \\
\hline Nev. Acid Rxn. FC D8 & $100.5 \%$ & $99.7 \%$ & $100.1 \%$ & $0.5 \%$ & - \\
\hline Nev. Acid Rxn. FC D9 & $101.8 \%$ & $98.4 \%$ & $100.1 \%$ & $2.4 \%$ & - \\
\hline Nev. Acid Rxn. FC D11 & $105.4 \%$ & $103.1 \%$ & $104.2 \%$ & $1.6 \%$ & - \\
\hline Nev. Acid Rxn. FC D12 & $96.1 \%$ & $94.5 \%$ & $95.3 \%$ & $1.1 \%$ & 19.1 \\
\hline Nev. Acid Rxn. FC D14 & $102.1 \%$ & $97.8 \%$ & $99.9 \%$ & $3.0 \%$ & 20.0 \\
\hline Nev. Acid Rxn. FC D15 & $103.4 \%$ & $95.2 \%$ & $99.3 \%$ & $5.8 \%$ & 19.9 \\
\hline Nev. Acid Rxn. FC D16 & $100.9 \%$ & $98.6 \%$ & $99.7 \%$ & $1.6 \%$ & 19.9 \\
\hline Nev. Acid Rxn. FC D17 & $104.2 \%$ & $100.6 \%$ & $102.4 \%$ & $2.5 \%$ & - \\
\hline Nev. Acid Rxn. FC D18 & $110.7 \%$ & $104.4 \%$ & $107.5 \%$ & $4.4 \%$ & - \\
\hline Nev. Acid Rxn. FC D19 & $95.8 \%$ & $92.9 \%$ & $94.4 \%$ & $2.1 \%$ & 18.9 \\
\hline Nev. Acid Rxn. FC D20 & $50.8 \%$ & $44.9 \%$ & $47.8 \%$ & $4.2 \%$ & 9.6 \\
\hline Nev. Acid Rxn. FC D21 & $57.6 \%$ & $54.3 \%$ & $56.0 \%$ & $2.4 \%$ & 11.2 \\
\hline Nev. Acid Rxn. FC D22 & $26.2 \%$ & $21.6 \%$ & $23.9 \%$ & $3.3 \%$ & 4.8 \\
\hline Nev. Acid Rxn. FC D23 & $1.2 \%$ & $0.9 \%$ & $1.1 \%$ & $0.2 \%$ & 0.2 \\
\hline Nev. Acid Rxn. FC D24 & $0.0 \%$ & $0.1 \%$ & $0.1 \%$ & $0.0 \%$ & 0.02 \\
\hline Nev. Acid Rxn. FC D25 & $0.1 \%$ & $0.1 \%$ & $0.1 \%$ & $0.0 \%$ & 0.02 \\
\hline Nev. Acid Rxn. FC D26 & $16.6 \%$ & $14.8 \%$ & $15.7 \%$ & $1.3 \%$ & 3.1 \\
\hline
\end{tabular}




\begin{tabular}{|c|c|c|c|c|c|} 
& & & 13.7 \\
\hline Nev. Acid Rxn. FC D27 & $72.2 \%$ & $65.1 \%$ & $\mathbf{6 8 . 7} \%$ & $\mathbf{5 . 0 \%}$ & 19.3 \\
\hline Nev. Acid Rxn. FC D28 & $99.9 \%$ & $93.0 \%$ & $\mathbf{9 6 . 5} \%$ & $\mathbf{4 . 9} \%$ & 19.1 \\
\hline Nev. Acid Rxn. FC D29 & $101.7 \%$ & $89.6 \%$ & $\mathbf{9 5 . 7} \%$ & $\mathbf{8 . 6 \%}$ & 19.3 \\
\hline Nev. Acid Rxn. FC D30 & $107.4 \%$ & $85.6 \%$ & $\mathbf{9 6 . 5} \%$ & $\mathbf{1 5 . 4 \%}$ & \\
\hline Nev. Acid Rxn. FC D34 & $104.1 \%$ & $91.1 \%$ & $\mathbf{9 7 . 6} \%$ & $\mathbf{9 . 2} \%$ & \\
\hline
\end{tabular}

${ }^{*}$ The calculation is based on the assumption that the relationship between antiviral activity and test compound concentration is linear; - where viral activity is $\geq 100 \%$ at $10 \mu \mathrm{g} / \mathrm{mL}$, the $I_{50}$ could not be calculated. 

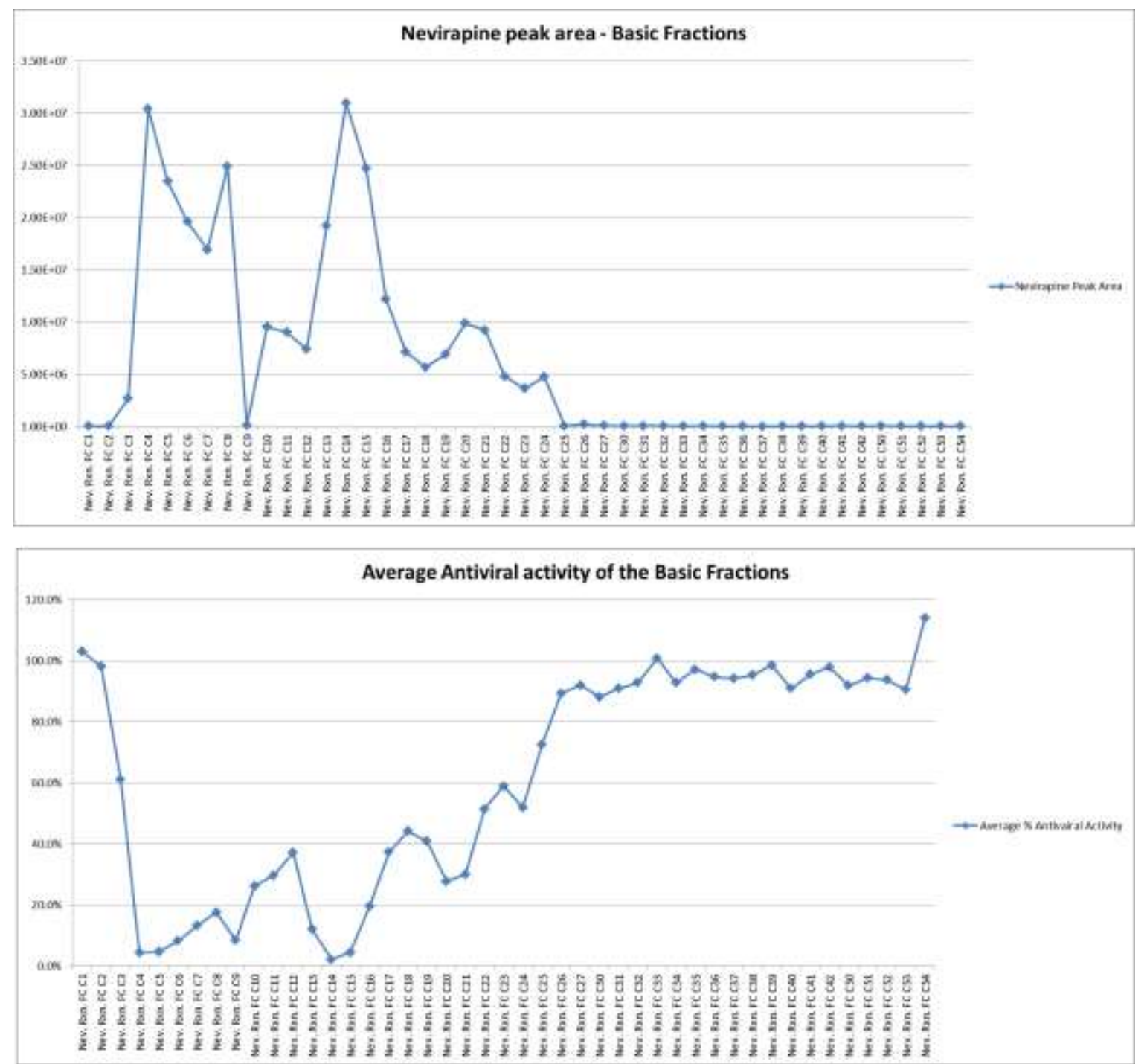

Figure S5: The peak area of the extracted Nevirapine ion analysed by UHPLC-QTOF (top) and the average antiviral activity (bottom) of each of the chlorination reaction preparative chromatography fractions. 